\title{
SACRIFICING FISH FOR POWER: A LEgAL History OF THE SPRAY LAKES DEVELOPMENT
}

\author{
SARAH NYKOLAISHEN AND NIGEL BANKES*
}

This article tells the story of how Calgary Power acquired a legal licence to divert and store water in the Spray Lakes Reservoir, how multiple legal instruments, including the National Parks Act, Alberta's Water Resources Act, and the Natural Resources Transfer Agreement were shaped along the way, as well as details the subsequent efforts that have been made to restore stream flows to the Spray River and rehabilitate its native cutthroat trout population. This article highlights many of the challenges that older hydro-developments pose to aquatic ecosystem health and instream flow needs, while demonstrating that the law can be shaped in interesting ways through the dual pressure of economic growth and environmentalism. This story offers food for thought as Canadian environmental legislation appears poised to undergo significant change.
Cet article raconte comment Calgary Power a obtenu un permis légal pour détourner et entreposer l'eau du réservoir Spray Lakes,de quelle manière de nombreux instruments juridiques ont été façonnés en cours de route, dont la Loi sur les parcs nationaux, la Loi sur les ressources en eau de l'Alberta et l'Accord de transfert des ressources naturelles, ainsi que les détails des efforts subséquents faits pour rétablir le débit de la Spray River et réintégrer la population indigène de truite fardée. Cet article souligne les nombreux problèmes que les aménagements hydroélectriques plus anciens posent pour la santé d'un écosystème aquatique et les besoins en eau de ruissellement et démontre à la fois que la loi peut être formulée de manières intéressantes par la double pression de la croissance économique et l'environnementalisme. Cet article donne matière à réflexion à un moment où les lois canadiennes sur l'environnement s'apprêtent à subir de profonds changements.

\section{TABLE OF CoNTENTS}

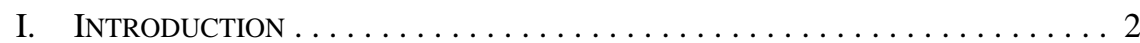

II. THE SPRAY LAKES VALLEY AND SPRAY RIVER $\ldots \ldots \ldots \ldots \ldots \ldots \ldots 4$

III. THE SPRAY LAKES DEVELOPMENT $\ldots \ldots \ldots \ldots \ldots \ldots \ldots \ldots \ldots \ldots$

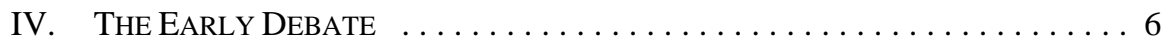

V. Dealings Between Calgary Power

AND the PRovince of Alberta $\ldots \ldots \ldots \ldots \ldots \ldots \ldots \ldots \ldots$

VI. Dealings Between Calgary Power

AND THE FEDERAL GOVERNMENT $\ldots \ldots \ldots \ldots \ldots \ldots \ldots \ldots \ldots$

VII. Final Steps at the Provincial LeVel $\ldots \ldots \ldots \ldots \ldots \ldots \ldots \ldots . \ldots \ldots$

VIII. EFFORTS TO RESTORE THE SPRAY RIVER'S

AquATIC ECOSYTEM: 1975-1981 . . . . . . . . . . . . . . . . . . 21

IX. LATER EFFORTS TO RESTORE THE SPRAY RIVER'S

AquATIC ECOSYTEM: 1996-PRESENT $\ldots \ldots \ldots \ldots \ldots \ldots \ldots \ldots$

X. PARAgraph 16 OF THE Alberta

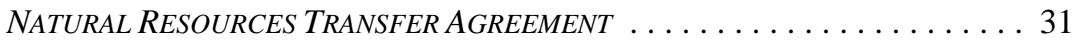

Sarah Nykolaishen, Student-at-Law, Alberta Court of Appeal, sarahjnyk@gmail.com and Nigel Bankes, Professor of Law, University of Calgary, ndbankes@ucalgary.ca. This research on water law is supported by a grant from Alberta Ingenuity. The authors wish to thank Karen Simonson and Hagit Hadaya for locating and retrieving archival material, and Charlie Pacas and Roger Drury for speaking with us about the Spray Lakes Development and commenting on an earlier draft of the article. Thanks also to Jenny Earle, Dave Mayhood, Brian Meagher, and Jim Stelfox for providing us with helpful background information and to Professor Jamie Benidickson, University of Ottawa and the Alberta Law Review's two anonymous reviewers for helpful comments on the manuscript. 


\section{What Does the SpRay LaKes DeVelopment STORY \\ Tell Us About Resource DeVELOPMENT DeCisions? . . . . . . . . . . . . . 33}

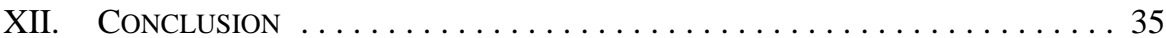

\section{INTRODUCTION}

The Spray Lakes Reservoir is a $21 \mathrm{~km}$ long, narrow impoundment located $400 \mathrm{~m}$ above the town of Canmore, Alberta. ${ }^{1}$ Calgary Power Company Ltd. (Calgary Power), now TransAlta Corporation (TransAlta), built the storage reservoir in 1949 to facilitate hydroelectric generation at three power plants between the north end of the reservoir and Canmore. The company also erected two control dams, one, the Canyon Dam, on the southeast side of the reservoir to divert water from the Spray River into the reservoir, and another, the Three Sisters Dam, at the north end of the reservoir to regulate flows to the power plants. The "Spray Lakes Development" (that is, the reservoir, control dams, and power plants) has had major impacts on the Spray River, which once flowed directly through the reservoir site. In particular, the development significantly reduces stream flows and water depths below the Canyon Dam from their historic levels. The development has also had an impact on flows in Goat Creek, a tributary of the Spray River. These changes, in combination with other factors such as the introduction of non-native brook trout, have adversely affected native fish populations in the Spray River, including the westslope cutthroat trout. ${ }^{2}$ Prior to the construction of the Spray Lakes Reservoir, the Spray River was home to an abundance of cutthroat trout and was the premier angling stream in Banff National Park (BNP). ${ }^{3}$ Today, the species has been virtually extirpated from this portion of its native range.

This article tells the story of how Calgary Power acquired its licence to divert and store water in the Spray Lakes Reservoir, how multiple legal instruments were shaped along the way, including the National Parks Act, ${ }^{4}$ Alberta's Water Resources Act, ${ }^{5}$ and a constitutional instrument, the Natural Resources Transfer Agreement, ${ }^{6}$ and the subsequent efforts that have been made to restore stream flows in the Spray River and rehabilitate its native cutthroat trout population since the development. The story is relevant today for a number of reasons.

Patricia Mitchell \& Ellie Prepas, eds, Atlas of Alberta Lakes (Edmonton: University of Alberta Press, 1990) at 583, online: Atlas of Alberta Lakes <http://alberta-lakes.sunsite.ualberta.ca/>.

In November 2006, the Committee on the Status of Endangered Wildlife in Canada (COSEWIC) designated the remaining genetically pure populations of westslope cutthroat trout inhabiting the native range in Alberta as threatened, or likely to become endangered if limiting factors are not reversed. See Allan B Costello, Status of the Westslope Cutthroat Trout (Oncorhynchus clarkii lewisii) in Alberta (Edmonton: Alberta Sustainable Resource Development and Alberta Conservation Association, 2006), online: Alberta Environment and Sustainable Resource Development <http://www.srd.alberta.ca/Fish Wildlife/SpeciesAtRisk/DetailedStatus/documents/WCTR.pdf $>$. The species is currently being considered for listing under the federal Species at Risk Act, SC 2002, c 29 [SARA]. See "Aquatic Species at Risk - The Westslope Cutthroat Trout (Alberta Population)," online: Fisheries and Oceans Canada $<$ http://www.dfo-mpo.gc.ca/species-especes/species-especes/slopecutthroattrout-truitefardee-eng.htm> . See Dave W Schindler \& Charlie Pacas, "Cumulative Effects of Human Activity on Aquatic Ecosystems in the Bow Valley of Banff National Park," in Jeffrey Green et al, eds, Ecological Outlooks Project: Cumulative Effects Assessment and Futures Outlook - Final Report (Ottawa: Department of Canadian Heritage, 1996) 5-i.

SC 1930 , с 33.

RSA 1942, с 65 [WRA].

Being a Schedule to the Constitution Act, 1930 (UK), 20 \& 21 Geo V, c 26 (previously named the British North America Act, 1930) [Alberta NRTA]. The agreement is also ratified by federal and provincial legislation: The Alberta Natural Resources Act, SA 1930, c 21 and the Alberta Natural Resource Act, SC 1930, c 3. It is, therefore, part of the Constitution of Canada. 
First, it highlights many of the challenges that older hydro developments, like the Spray, pose to aquatic ecosystem health and instream flow needs - two values that have come to play an increasingly important role in Alberta's water law and policy. ${ }^{7}$ Also, with respect to instream flow, the story illustrates the opportunities and challenges that arise where water bodies cross jurisdictional boundaries. In this case, the upstream development on provincial Crown lands compromises flows downstream in the federal jurisdiction of BNP.

Second, the story demonstrates how law, and even the Constitution, can be shaped in interesting ways through the dual pressures of economic growth and environmentalism (or the desire to preserve beauty in nature). Because of the Spray Lakes Development, paragraph 16 of the Alberta NRTA provides the federal government with the right to set a minimum flow requirement for the Spray River at its junction with the Bow River in Banff. This right was intended to help to "preserve the scenic beauties" of the park. It was also the result of a concession by the federal government to the Province of Alberta, in which the federal government excluded lands from the national parks to allow natural resources within those lands to be developed by the province. Few scholars have looked closely at paragraph 16 of the Alberta NRTA, the circumstances surrounding its adoption, or the question of whether it might serve as legal basis to increase flows in the Spray River today.

Third, the story of the Spray Lakes Development features two tendencies that can and do affect decision-making about natural resources in the present day, albeit to a lesser extent than in the early half of the twentieth century. The first is the reluctance on the part of decision-makers to take the time or to devote the necessary resources to understand the full implications of large-scale resource development projects. The second is a tendency among decision-makers to favour corporate interests and the immediate needs of the economy over the long-term needs of the environment. This story brings these tendencies into stark relief, and offers food for thought as Canadian environmental legislation seems about to undergo significant change. ${ }^{8}$

The article proceeds as follows. The first section describes the Spray Lakes Valley and the Spray River before the reservoir was filled in 1950. This is followed by a brief description of the Spray Lakes Development. Next, we discuss the debate about the development in the

In 1999, Alberta introduced the Water Act, RSA 2000, c W-3 which recognizes the need to "manage and conserve water resources to sustain our environment and to ensure a healthy environment" (ibid, s 2(a)). At the policy level, the province introduced the "Water for Life" strategy in 2003, which calls for the adoption of aquatic ecosystem-based water conservation objectives as a matter of policy. See Michael M Wenig, Arlene J Kwasniak \& Michael S Quinn, "Water Under the Bridge? The Role of Instream Flow Needs (IFNs) Determinations in Alberta's River Management” in H Epp \& D Ealey, eds, Water: Science and Politics (Proceedings of the Conference held by the Alberta Society of Professional Biologists, Calgary, 25-29 March 2006), online: Canadian Institute of Resources Law <http://www.cirl.ca/files/ cirl/IFN-Determin.pdf $>$ at 15. The current and previous versions of the "Water for Life" strategy are available online: Government of Alberta - Water for Life <http://www.cirl.ca/system/files/IFNFed.pdf $>$.

8 As we were finalizing the text of this article, Bill C-38, An Act to implement certain provisions of the budget tabled in Parliament on March 29, 2012 and other measures, 1st Sess, 41st Parl, 2011 (assented to 29 June 2012), SC 2012, c 19, was introduced in the House and was subsequently passed and assented to. The Bill as proclaimed replaces the Canadian Environmental Assessment Act, SC 1992 c 37, and makes significant changes to the Fisheries Act, RSC 1985, c F-14, SARA, supra note 2, and the National Energy Board Act, RSC 1985, c N-7. With respect to the Fisheries Act, the Bill amends section 35, which made it an offence to carry on any work or undertaking that results in a harmful alteration, disruption, or destruction of fish habitat (HADD). The Bill amends section 35 in two stages, with some amendments taking effect as of the date of proclamation and others on a date to be fixed by order in council. 
1920s, leading up to the conclusion of the Alberta NRTA. From there we move on to consider the bargaining between Calgary Power and the provincial and federal governments in 1948 and 1949, until the company received its interim licence under the WRA. The next two sections describe efforts to increase stream flows and restore fish habitat in the Spray River, decades after the development, first from the mid-1970s to the early 1980s, and then from the mid-1990s to the present day. We then take a closer look at paragraph 16 of the Alberta NRTA, and ask whether it might be used to improve the state of the Spray River today. Finally, we reflect on two significant features of the story of the Spray Lakes Development: the failure of key decision-makers to use science to examine the full implications of the Spray Lakes Development before construction began, and the extent to which decisionmakers favoured corporate power interests over those of other affected parties. ${ }^{9}$

\section{THE SPRAY LAKES VALLEY AND SPRAY RIVER}

The Spray Lakes Valley is situated between the Goat and Kananaskis ranges on the outskirts of the southeast boundary of BNP. The valley was within the boundaries of BNP until 1949. The valley contained two small lakes running north-south in direction. The northern lake (Upper Spray Lake) was about $1.6 \mathrm{~km}$ long and the southern lake (Lower Spray Lake) was about $3 \mathrm{~km}$ long. Upper Spray Lake drained into Lower Spray Lake via a 5 kmlong creek (Buller Creek). Lower Spray Lake then drained into Woods Creek, which ran for just under $3 \mathrm{~km}$ before joining the Spray River. For a depiction of the Spray Lakes Valley and the Spray River, see Figure 1 below.

The Spray River flows north to meet the Bow River in Banff, just downstream of Bow Falls and immediately below the site of the Banff Springs Hotel. Prior to the construction of the Spray Lakes Development, the river was divided by natural falls (the Spray Falls). South of the falls, a number of tributaries joined the river, including Bryant Creek and Turbulent Creek. North of the falls, the river was joined by Smuts Creek and Woods Creek (carrying flow from the Spray Lakes). Stream flow from the upper Spray River watershed (that is, all points south of the Canyon Dam) is now stored in the Spray Lakes Reservoir. ${ }^{10}$ Past the point that is now the Canyon Dam, and north of the Spray Lakes Reservoir, the Spray River runs for approximately $39 \mathrm{~km}$ in a north-westerly direction before joining the Bow, as noted above. The only major tributary in this stretch of the river is Goat Creek, which originates at the north end of what is now the Spray Lakes Reservoir. Goat Creek is sometimes used on an emergency basis to spill water from the reservoir.

The Spray Lakes and the Spray River used to abound with fish, including cutthroat trout, bull trout, and mountain whitefish. Anglers harvested upwards of several thousand fish per year, many of them up to $58 \mathrm{~cm}$ in length. ${ }^{11}$ In the spring of 1949, before Calgary Power began filling the Spray Lakes Reservoir, scientists R.B. Miller and W.H. MacDonald studied the fish species in the Spray Lakes and the Spray River as part of a wider survey of Alberta's

$9 \quad$ We rely on correspondence between officials from Calgary Power and the federal and provincial governments to tell the story of the Spray Lakes Development. These sources are archived at the National Archives of Canada (PAC), the Provincial Archives of Alberta (PAA), and the Calgary office of Alberta Environment and Water (ABEW).

10 Peter Eaton, Assessment and Recommendations: Spray River Restoration, Banff National Park(MEDes Thesis, University of Calgary, 2004) at 8 [unpublished].

Schindler \& Pacas, supra note 3 at 5-18. 
watersheds, commissioned by the provincial Department of Land and Forests. ${ }^{12}$ The scientists focused on cutthroat trout, the most important species for the valley's sport fishery.

\section{FIGURE $1^{13}$}

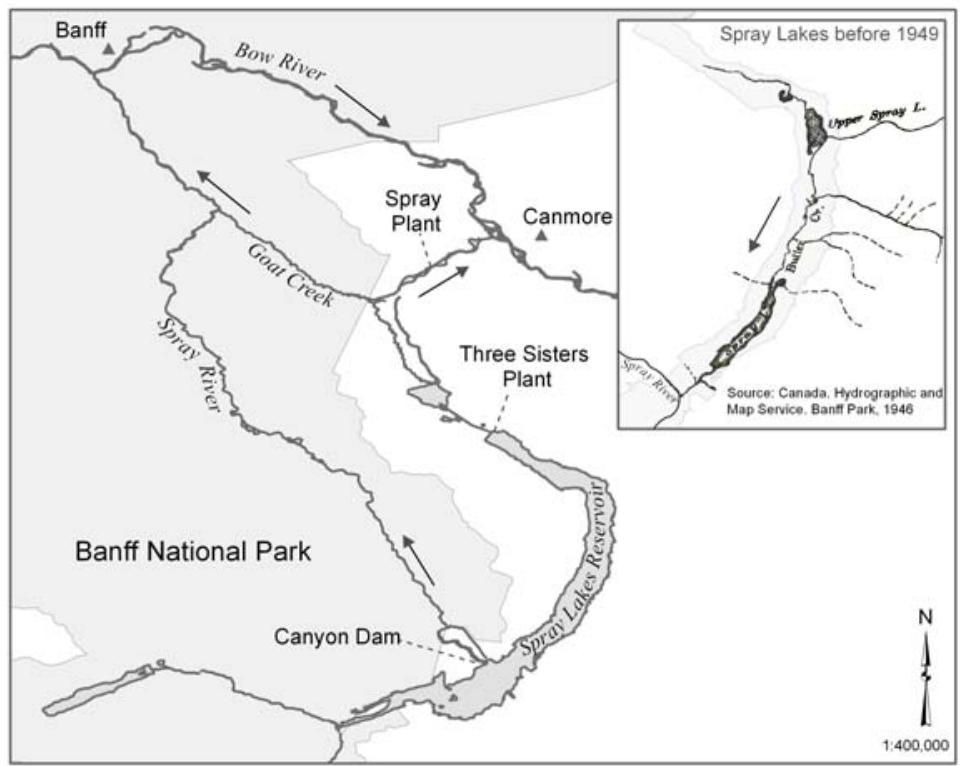

Miller and MacDonald identified four populations of cutthroat in the Spray system: above the Spray Falls, in the Spray Lakes, downstream of the Spray Falls to within $24 \mathrm{~km}$ of Banff, and in the final $24 \mathrm{~km}$ stretch of the Spray River before it joins the Bow. ${ }^{14}$ The largest population of the cutthroat, both in terms of size and number, inhabited the lakes and used the gravel beds in Buller Creek and Woods Creek for spawning. ${ }^{15}$ The second largest population lived in the river below the Spray Falls to within $24 \mathrm{~km}$ of Banff. Crucially, Miller and MacDonald concluded that members of this population migrated from Lower Spray Lake. ${ }^{16}$ The scientists located fewer fish in the upper and lower reaches of the Spray River, and the fish in these reaches were also small in comparison to those living in or near the lakes. Miller and MacDonald noted that the four populations were distinct - each exhibited different flesh colour and egg colour, as well as different rates of growth. ${ }^{17}$

RB Miller \& WH MacDonald, The Effect of the Spray Lakes Development on the Sport Fishery (1949) [unpublished], Edmonton, PAA (GR 1991.0100, file LSR S53).

Map prepared by Iris Morgan, Information Specialist, Spatial and Numeric Data Services, The University of Calgary Libraries and Cultural Service.

Miller \& MacDonald, supra note 12 at 5.

Ibid.

Ibid at 6.

Ibid at 6-7. 


\section{THE SPRAY LAKES DEVELOPMENT}

The most important aspect of the Spray Lakes Development is the Spray Lakes Reservoir. Calgary Power built the reservoir, in large part, to increase the efficiency of its existing facilities, particularly the Horseshoe Plant (built in 1911) and the Kananaskis Plant (built in 1913), two run-of-the-river plants on the main stem of the Bow River. ${ }^{18}$ In the fall and winter months, low flows in the Bow River caused the Horseshoe and Kananaskis plants to generate much less power than they were capable of producing. ${ }^{19}$ The Spray Lakes Reservoir helped to correct this problem by holding back water during the spring and summer and then releasing it in the fall and winter. The reservoir was originally designed with a capacity of 210,000 acre-feet, but in the early 1990s concerns over ongoing leakage around and under the Three Sisters Dam led TransAlta to reduce the reservoir level by $4 \mathrm{~m}$, thereby reducing its storage capacity to 144,000 acre-feet.

Calgary Power set its sights on developing upstream storage in the Spray Lakes Valley because of the area's potential for electrical power generation. The company's Chief Engineer, G.A. Gaherty, recognized that once the outflow of the Spray Lakes had been blocked off, water could be diverted north, towards Canmore, over a series of drop-offs. ${ }^{20}$ Calgary Power built three power plants to take advantage of this head. The plant nearest to the reservoir, the Three Sisters Plant (3 MW), serves mainly to control the release of water from the reservoir. ${ }^{21}$ Water is then channelled through the Goat Valley Canal and held in a headpond by Whiteman's Dam before dropping 275 m to the Spray Plant (103 MW). From there, water flows down the Rundle Canal and falls about $100 \mathrm{~m}$ to the Rundle Plant (50 MW) before joining the Bow River. Altogether, the three plants on the Spray system generate about 287,200 megawatt hours each year. ${ }^{22}$

\section{THE EARLY DeBATE}

Demand for electricity in Alberta was growing in the 1920 s. $^{23}$ As noted above, Calgary Power hoped to service this demand by developing upstream storage to increase the efficiency of its existing facilities on the Bow River system. Many of the best upstream storage sites on the Bow River system were located inside the boundaries of BNP. Initially, this was not a problem for the company. Few protests were raised in 1912 when Calgary Power dammed a storage reservoir on Lake Minnewanka, near the town of Banff. ${ }^{24}$ However, in 1922, when Calgary Power renewed its 1920 request to dam the Spray Lakes, groups such as the Calgary Automobile Club and the Banff Citizens' Council began to question whether

Christopher Armstrong, Matthew Evenden \& HV Nelles, The River Returns: An Environmental History of the Bow (Montreal \& Kingston: McGill-Queen’s University Press, 2009) at 128.

Ibid.

Ibid at 132.

"Three Sisters" (27 August 2009), online: TransAlta <http://www.transalta.com/facilities/plantsoperation/three-sisters>.

Ibid; "Spray" (11 August 2011), online: TransAlta <http://www.transalta.com/facilities/plantsoperation/spray>; "Rundle" (27 August 2009), online: TransAlta <http://www.transalta.com/facilities/ plants-operation/rundle>.

23 PearlAnn Reichwein, “'Hands Off Our National Parks': The Alpine Club of Canada Hydro-development Controversies in the Canadian Rockies, 1922-1930" (1995) 6:1 Journal of the Canadian Historical Association 129 at 141.

$24 \quad$ Ibid at 142. 
it was appropriate to allow natural resources projects inside national park boundaries. ${ }^{25}$ The Dominion Parks Branch of the Department of the Interior, created under the 1911 Dominion Forest Reserves and Parks Act, ${ }^{26}$ also objected to the proposal. J.B. Harkin, the first Commissioner of Dominion Parks, had long been an advocate for the preservation of nature as a means of promoting tourism and recreation in the parks. ${ }^{27}$ By the time of the Spray Lakes proposal, Harkin was committed to the principle of "inviolability," or the idea that parks resources should not be developed only for the benefit of a certain section of the country or a private company. ${ }^{28}$ This opposition within his own department made it difficult for the federal Minister of the Interior, Charles Stewart, to reach a decision on the Spray Lakes proposal. $^{29}$

Another factor that caused Stewart to hesitate was the proximity of the Spray River's final stretch to popular tourist attractions owned by the Canadian Pacific Railway (CPR) — the Banff Springs Hotel and golf course. The CPR was concerned that damming the Spray River might have an adverse effect on the scenery near these facilities, as well as the operations of these facilities. In particular, the company relied on the Spray River to flush sewage away from the hotel and into the fast-flowing and larger volumes of the Bow River.

The CPR voiced its concerns to Minister Stewart, and reminded him that millions of dollars had been spent on the Banff Springs Hotel. ${ }^{30}$ The Minister responded by informing Calgary Power that in order to receive an approval to build the Spray Lakes Reservoir, the company would have to release water from the reservoir into the Spray River in the summer months - enough to maintain a flow rate of 500 cubic feet per second (cfs). ${ }^{31}$ Gaherty replied that he was unwilling to maintain such a large flow — it would reduce the amount of water stored in the reservoir such that the project would no longer be economical. Stewart

Ibid.

SC 1911, с 10.

Shaun Fluker, “Ecological Integrity in Canada’s National Parks: The False Promise of Law” (2010) 29:1 Windsor Rev Legal Soc Issues 89 at 118.

28 CJ Taylor, "Legislating Nature: The National Parks Act of 1930" in Rowland Lorimer, et al, eds, To See Ourselves/To Save Ourselves: Ecology and Culture in Canada (Victoria, BC: Association for Canadian Studies, 1991) 125 at 130.

29 The federal government's jurisdiction to approve the Spray Lakes proposal stemmed from the location of the Spray Lakes Valley on federal land, inside BNP. The federal government's right to legislate in relation to national parks derives from the "Public Debt and Property" head of section 91(1A) of the Constitution Act, 1867 (UK), 30 \& 31 Vict, c 3, reprinted in RSC 1985, App II, No 5. For discussion of this jurisdiction, see ND Bankes, "Constitutional Problems Related to the Creation and Administration of Canada's National Parks” in J Owen Saunders, ed, Managing Natural Resources in a Federal State: Essays from the Second Banff Conference on Natural Resources Law (Toronto: Carswell, 1986) 212 at 213-17 [Bankes, "Constitutional Problems"]. Given the timing of the proposal, the project would still have required federal approval, even outside the park, since the administration and control of Alberta's public lands and natural resources remained with the federal government from 1905, when the province was carved out of the North-Western Territory, until the Alberta NRTA was implemented in 1930. For a discussion of federal justifications for maintaining control over the province's public lands and natural resources, see Nicole Colleen O’Byrne, The Answer to the 'Natural Resources Question': A Historical Analysis of the Natural Resources Transfer Agreements (LLM Thesis, McGill University, 2005) at 4546, online: McGill Library and Collections eScholarship@Mcgill <http://digitool.library.mcgill.ca/R/?func=dbin-jump-full\&object_id=99147\&silo_library=GEN01> [unpublished]. Armstrong, Evenden \& Nelles, supra note 18 at 135. Ibid. 
dropped the flow requirement to $350 \mathrm{cfs}$ but this was still too high for Gaherty, who was unwilling to agree to any more than $200 \mathrm{cfs}^{32}$

The “Spray Lakes Question” remained undecided as Ottawa and Alberta drew closer to concluding an agreement to transfer control over the province's natural resources. Premier John Brownlee was keen to see the province gain control over its own natural resources, but he was also reluctant to conclude an agreement that would leave the federal government in control of all the natural resources located inside national parks. Brownlee was particularly concerned about leaving park resources in federal hands, in light of proposed amendments to the Dominion Forest Reserves and Parks Act that would enshrine the principle of inviolability and prohibit the Department of the Interior from disposing of any park resources without the approval of Parliament. ${ }^{33}$ Thus, with an eye to ensuring that Alberta would one day be able to develop some of the resources located inside of national parks, Brownlee proposed redrawing their boundaries to exclude resource-rich areas. The federal government, anxious at this point to conclude an agreement with the province, accepted Brownlee's suggestion and sent surveyor R.W. Cautley to investigate and report on new potential boundaries for Banff and Jasper National Parks. Cautley's report identified several resourcerich areas to be removed from the parks, including the Spray Lakes watershed. ${ }^{34}$ The first half of section 16 of the Alberta NRTA refers to these areas and the federal government's promise to transfer them into provincial hands:

The Government of Canada will introduce into the Parliament of Canada such legislation as may be necessary to exclude from the parks aforesaid certain areas forming part of certain of the said parks which have been delimited as including the lands now forming part thereof which are of substantial commercial value, the boundaries of the areas to be so excluded having been heretofore agreed upon by representatives of Canada and of the Province. ${ }^{35}$

When Ottawa entered into serious NRTA negotiations with Alberta, there was still no agreement in place with Calgary Power to ensure a minimum flow in the Spray River. This became an important consideration for Ottawa because the authority to permit the Spray Lakes Development would pass to the province upon the conclusion of the Alberta NRTA (and once Parliament passed legislation to exclude the watershed from BNP). Thus, to ensure that the CPR's interests would be protected in the future, the federal government bargained for a way to establish a binding minimum flow rate for the Spray River. ${ }^{36}$ This led to the second half of section 16 of the Alberta NRTA, which reads:

Ibid. The federal government's willingness to act in the interests of the CPR was probably a product of their historical relationship. The Canadian government helped the CPR to monopolize development inside of Banff following the creation of the park in 1886. This included granting the CPR a 999 year lease on lands inside the park (leases for other homes and businesses lasted only 42 years). The CPR built the Banff Springs Hotel in 1887, and again in 1926 after a fire destroyed the original hotel. The government also gave the CPR a lease on land in the Banff town site, which the company exchanged in the 1930s for land adjacent to its hotel. That land is now used as a golf course. See Leslie Bella, Parks for Profit (Montreal: Harvest House, 1987) at 10-14.

WF Lothian, A History of Canada's National Parks, vol 2 (Ottawa: Parks Canada, 1977) at 16.

Ibid at 17.

Alberta NRTA, supra note 6.

The federal Minister of Mines and Resources, JA MacKinnon wrote to the CPR's president, William A Mather in April 1948. Referring to section 16 of the Alberta NRTA, MacKinnon wrote, "I may say that the Spray Lakes was the principal concern at the time this arrangement was agreed upon": Letter from JA MacKinnon to William A Mather (24 April 1948), Ottawa, PAC (RG 22, vol 238, file 33-4-10, pt $1)$. 
[T] ]e Province agrees that upon the exclusion of the said areas as so agreed upon, it will not, by works outside the boundaries of any of the said parks, reduce the flow of water in any of the rivers or streams within the same to less than that which the Minister of the Interior may deem necessary adequately to preserve the scenic beauties of the said parks. ${ }^{37}$

Alberta and Ottawa concluded the NRTA in December 1929. Shortly afterwards, Parliament passed the Alberta Natural Resources Act, which confirmed Alberta's control over its lands and natural resources. The Alberta Natural Resources Act received royal assent on the same day as the National Parks Act. The National Parks Act confirmed Canada's exclusive legislative jurisdiction over national parks, but revised the boundaries of BNP to exclude the Spray Lakes watershed. ${ }^{38}$ The National Parks Act also provided that no further changes could be made to the boundaries of an existing park, except by an act of Parliament, and dedicated the parks to be preserved for the use and enjoyment of all Canadians:

The Parks are hereby dedicated to the people of Canada for their benefit, education and enjoyment, subject to the provisions of this Act and Regulations, and such Parks shall be maintained and made use of so as to leave them unimpaired for the enjoyment of future generations. ${ }^{39}$

While Calgary Power's plan to transform the Spray Lakes Valley into a storage reservoir became more feasible with the conclusion of the Alberta NRTA and the exclusion of the valley from BNP under the National Parks Act, the company did not seek approval for the project immediately. The demand for power in Alberta had declined in the 1930s, in line with the steadily worsening economic depression. ${ }^{40}$ It was not until 1947 that Calgary Power submitted another application, this time to the provincial government. As we discuss below, the application had to satisfy both provincial and federal interests, for although the provincial government had the authority to issue a water licence, the project also required the federal government to act under section 16 of the Alberta NRTA and the National Parks Act. The next two sections describe the negotiations that took place between Calgary Power and both levels of government, starting with the dealings between the company and the province.

\section{Dealings Between Calgary Power AND The Province of Alberta}

Alberta enacted the WRA in 1931 upon assuming control of its provincial water under the Alberta NRTA. ${ }^{41}$ The WRA continued many of the key principles of the previous federal

Alberta NRTA, supra note 6.

RB Bennett, Leader of the Opposition (Conservative Party) and Member of Parliament for Calgary West, opposed federal control over park lands, calling the National Parks Act a "monstrous ... exercise of exclusive power by ... parliament”: House of Commons Debates, 16th Parl, 4th Sess, vol 2 (29 April $1930)$ at 1578.

Supra note 4, s 4(1).

Armstrong, Evenden \& Nelles, supra note 18 at 136.

There were some initial doubts as to whether water was one of the resources transferred to the province under the Alberta NRTA. Retroactive legislation resolved these doubts: see Natural Resources Transfer (Amendment) Act 1938, SC 1938, c 36; An Act to Ratify a certain Agreement between the Government of the Dominion of Canada and the Government of the Province of Alberta, SA 1938, c 14. For further discussion, see also David R Percy, "Seventy-Five Years of Alberta Water Law: Maturity, Demise \& Rebirth” (1996) 35:1 Alta L Rev 221 at 226 [Percy, “Alberta Water Law”]. 
legislation, the North-West Irrigation Act ${ }^{42}$ (later renamed the Irrigation Act ${ }^{43}$ ), which largely replaced the common law system of riparian rights with a system of prior appropriation or allocation. ${ }^{44}$ Under the WRA, the province could licence the diversion and use of water. ${ }^{45}$ To obtain a licence, an applicant had to file an application with the Minister, setting out the nature and purpose of the proposed diversion. ${ }^{46}$ The Minister would then grant a preliminary permit authorizing the work necessary to assemble a more detailed proposal (that is, examinations and surveys) ${ }^{47}$ Applicants would submit a detailed proposal when applying for an interim licence. ${ }^{48}$ Interim licence applications triggered a notice requirement. Details of an application would be posted at the site of the intended works or in the local newspapers of nearby municipalities, and people could file objections for 30 days. The Minister had complete freedom to accept or reject objections raised by the public. In some cases, the Minister might require changes to a proposal or impose conditions on a licence, but would ordinarily issue an interim licence authorizing construction of the proposed works. ${ }^{49}$

Calgary Power applied for a preliminary permit to survey the Spray Lakes Valley in June 1947. The province had been in favour of developing the Spray Lakes Valley for storage and hydro-generation purposes since the early 1920s, and, thus, welcomed the application, especially in light of the growing demand for electricity in Alberta. ${ }^{50}$ Alberta's Director of Water Resources, Ben Russell, also viewed the application as an opportunity to address a problem that had been plaguing the City of Calgary - ice-jamming on the Bow River, which caused flooding in the surrounding area. In a letter to the Department of the Attorney General, Russell explained that Calgary Power's hydro-electric operations were contributing to the problem of ice-jamming by increasing the Bow River's average winter flows and making them more irregular. ${ }^{51}$ According to Russell, the best protection against ice-jamming would be to build a dam ten miles north of Calgary at the "Bearspaw Site."52 Russell informed Calgary Power of the need for this new facility and advised the company to

SC 1894, с 30.
RSC 1906 , с 61.

Under the doctrine of riparian rights, only those who owned lands adjoining a watercourse were allowed to use water for domestic purposes. Riparian owners could use water for non-domestic purposes only if the quantity consumed did not perceptibly diminish the natural flow of the watercourse. The NorthWest Irrigation Act replaced the common law doctrine riparian rights and put in place instead a scheme for the allocation of water similar to that which had been used for the disposition of other natural resources in Western Canada. That is, the Crown could issue licences for the diversion and use of specified quantities of water, and licences could be granted for all land, whether or not it adjoined a watercourse. The priority of the licence depended upon the date of application. See Percy, "Alberta Water Law," supra, note 41 at 222-23.

45 WRA, supra note 5, s 5(2).

46 Ibid, s $11(2)$. For more on the application requirements, see David R Percy, "Water Rights in Alberta" (1977) 15:1 Alta L Rev 142 at 147 [Percy, "Water Rights”].

WRA, ibid, s 11(3).

Ibid, ss 12(1)-(3).

Percy "Water Rights," supra note 46 at 147.

The province was initially opposed to a private development. In 1923, the provincial legislature passed a motion calling on the federal government to refuse to grant a power licence to a private firm because hydroelectric power should be developed "for the benefit of the people." Alberta's Premier at the time, Herbert Greenfield, wrote to Charles Stewart, asking that the province be given the exclusive right to develop the Spray Lakes. The province warmed to the idea of a private development in 1925, after commissioning engineers from Ontario Hydro to investigate the costs of developing the Spray Lakes. The engineers' report showed that the development would be profitable only if it was operated in conjunction with the existing power developments owned by Calgary Power. See Christopher Gainor, “Alberta's Resources Negotiations and Banff and Jasper National Parks” (2005) 11 Past Imperfect 1 at 6.

51 Letter from Ben Russell to WS Gray, Solicitor, Attorney General's Department (22 April 1948), Calgary, ABEW (file 1552).

Ibid. 
withdraw its application for the Spray Lakes Development and make a new application under section 65 of the WRA for a "Spray-Bearspaw Development." 53

Calgary Power was willing to help the province deal with the problem of ice-jamming on the Bow River in exchange for the rights to store water in the Spray Lakes Valley, but a double development was not desirable from the company's point of view. ${ }^{54}$ Instead, the company entered into an agreement with the province under which it promised to build at Bearspaw upon the happening of certain events, and if required by the Minister. ${ }^{55}$ The recitals of the agreement acknowledge that Calgary Power would contribute to the costs of a system of protective dykes to be installed near low lying lands by the City of Calgary. ${ }^{56}$ The company would also build at Bearspaw if, after the completion of the initial development under the Spray Interim Licence, the Minister considered that the system of dykes "ha[d] not sufficiently alleviated surface flooding in the City of Calgary arising from ice conditions" and if, in the opinion of the Minister, two other conditions were met. ${ }^{57}$

Calgary Power's application to develop the Spray Lakes Valley also presented an opportunity for the company to get something that it wanted: an amendment to section 10 of the WRA. Sections 10(4) and 10(5) authorized the Minister to cancel an existing water right upon receiving an application to put the water to a higher priority use. Section 10(3) ranked water uses as follows, from highest to lowest priority: domestic, municipal, industrial, irrigation, water power, and other purposes. Calgary Power was wary of section 10 because storage at the head waters of the Bow River would decrease the summer flows available for irrigation. This created the potential for conflict between irrigation and water power purposes, and called into question the security of Calgary Power's rights. The company's legal counsel advised that this uncertainty would make it difficult for the company to obtain financing for the Spray Lakes Development. ${ }^{58}$ Hence, Calgary Power asked the province to amend the section, and in particular, to expand the powers of the Lieutenant Governor in Council under section 10(7) of the WRA to enable the Lieutenant Governor in Council to grant a permit or licence in relation to reserved waters that would not be subject to cancellation by reason of the water being subsequently required for any other purpose, unless so provided in such permit or licence. ${ }^{59}$ In other words, Calgary Power proposed that the

$53 \quad$ Ibid. Section 65 referred to applications for double-developments.

54 Ibid. Russell explained, "I think the main difficulty the Calgary Power Ltd. see about the double development is because of certain regulations to the [e]ffect that, if the Bearspaw is not completed, the license could be cancelled. Such a condition would make their financing difficult.”

55 The actual agreement was not signed until a year later: Memorandum of Agreement between His Majesty the King in the Right of the Province of Alberta, represented by The Honourable DA Ure, the Minister charged with the administration of the Water Resources Act of Alberta and Calgary Power Ltd, (6 May 1949), Calgary, ABEW (file 1552) [Memorandum of Agreement]. The preamble of this agreement states: "Whereas the Province considers it essential that in consideration of the granting of such Interim License [to develop the Spray Site] the Company should undertake to construct a dam and/or develop water-power at the Bearspaw Site on the Bow River upon the happening of the events hereinafter mentioned and if then so required by the Minister.” Ibid, preamble.

57 Ibid, clause 3. The first condition deals with load issues. The second condition requires the costs of constructing a plant or dam at Bearspaw to be warranted in light of "the benefits arising from the alleviation of ice trouble in the City of Calgary.”

58 Russell wrote to the Hon DB MacMillan, Alberta’s Minister in Charge of Water Resources and Irrigation on 3 March 1948, explaining that "[t]he Calgary Power Company has had legal advice to the [e]ffect that the above legislation [referring to section 10] is not sufficiently definite for the purpose of borrowing money for new construction and propose that Section 10 should be amended": Letter from Ben Russell to DB MacMillan (3 March 1948), Edmonton, PAA (Accession 72 302, file 193). Ibid. 
Crown reservation power should be used to grant licences that were immune from the use priority provisions.

Russell supported amending section 10, but felt that in the future it might be necessary to operate power reservoirs for the benefit of irrigation. ${ }^{60}$ Calgary Power's proposed amendment, if enacted on its own, would leave the province with no way to modify the rights granted through the Crown reservation provision, unless the licence itself provided for this possibility. To address this problem, Russell proposed an additional amendment to section 10 that would give the Lieutenant Governor in Council more discretion. Specifically, Russell suggested empowering the Lieutenant Governor in Council to authorize the Minister to enter into an agreement with a "reserved waters licensee" to amend the terms of, or terminate, its licence in cases where the water is required for another purpose. ${ }^{61}$

The Alberta government incorporated the proposed amendments of both Russell and Calgary Power into the WRA in the early spring of $1948 .^{62}$ As discussed below, the Lieutenant Governor in Council reserved the waters that were eventually granted to Calgary Power in the Spray Licence (that is, all the waters of the Spray River and Smith Dorrian Creek and their tributaries). The Lieutenant Governor in Council also made an order pursuant to section 10(7) of the WRA authorizing the grant of the Spray Licence. Hence, the Spray Licence was to be immune from third party applications to use the water allocated to Calgary Power for other higher priority purposes such as irrigation. ${ }^{63}$

Negotiations between Calgary Power and the province wrapped up in the spring of 1948 . It was then understood that the province would issue an interim licence for the Spray Lakes Development as soon as the federal government had taken certain steps. ${ }^{64}$ In exchange for the rights to transform the Spray Lakes Valley into a storage reservoir, Calgary Power had agreed to address ice-jamming on the Bow River by building another facility at Bearspaw. For its part, the province was willing to amend the WRA in exchange for Calgary Power's

Ibid. Russell wrote:

Although it has been determined from the study recently made of the Bow River flow that the development of Spray Lakes will not conflict with irrigation development as now planned, we cannot predict the future. It may be necessary, therefore, in some low flow year in the future, when the supply is even lower than in the lowest water year which has yet occurred, to operate the power reservoirs for the benefit of irrigation, in which case a further amendment to the Water Resources Act would be necessary.

$$
\text { Ibid. }
$$

An Act to amend The Water Resources Act, SA 1948, с 38. The "use trumping” mechanism in section 10 of the WRA was removed from Alberta's current water legislation, the Water Act, supra note 7, in 1999. The Water Act contains no equivalent mechanism, relying instead on market based transfers to meet new demands. See Nigel Bankes, "The Legal Framework for Acquiring Water Entitlements from Existing Users” (2006) 44:2 Alta L Rev 323.

Clause 13 of Calgary Power's interim licence makes it clear that sections 10(3)-(5) of the WRA did not apply to the licence. See Water Resources -Alberta, "Schedule 'A': Interim Licence for the Development of Storage and Water Power," signed by DA Ure, Minister in Charge of Water Resources and Irrigation (6 May 1949), Calgary, ABEW (file 1552-A) [Interim Licence].

See Letter from Ben Russell to DB MacMillan (15 May 1948), Calgary, ABEW (file 1552), Russell indicates that all necessary steps had been taken in preparation to grant to Calgary Power an interim licence. Russell wrote:

All of the provisions in the licenses and agreements have been given much careful consideration and have been checked by the solicitor of the Calgary Power Ltd. and by Mr. W.S. Gray, Legislative Counsel for the Alberta Government. It is my opinion that there is no other possible development now which could be completed in time to off-set the threat of a power shortage in the Province and that everything possible should now be done to assist the early construction of such a development. 
help in reducing flooding near Calgary, and, more importantly, in meeting Alberta's growing demand for electricity. Significantly, the province agreed to issue an interim licence for the development without examining its environmental impacts or considering whether Calgary Power might be required to modify its proposal for the benefit of fish habitat. This suggests that the province assumed that any environmental costs incurred by the development would be outweighed by its economic benefits. Having outlined the bargaining that took place at the provincial level, we now turn to consider the dealings between Calgary Power and the federal government.

\section{Dealings Between Calgary Power AND THE FEDERAL GOVERNMENT}

The federal government had to take two steps before Alberta could issue an interim licence to Calgary Power to divert and store water in the Spray watershed. First, it had to prescribe a minimum flow requirement for the Spray River, as required by section 16 of the Alberta NRTA. The authority to fix the flow requirement rested with James A. MacKinnon, the federal Minister of Mines and Resources. Second, the federal government would have to amend the National Parks Act to exclude yet more territory from BNP. This was necessary because Calgary Power had revised its original plan for the Spray Lakes Development. Instead of moving water from the Spray Lakes Reservoir to two power plants via a tunnel through Wind Mountain, the company planned instead to move water through a canal and pipeline through Whiteman's Pass. The revised plan required the removal of an additional 50 square kilometers from BNP to accommodate a 640 m-long, 14 m-high control dam and an earth dike running across the Goat Valley. ${ }^{65}$

The province wanted the federal government to act quickly so that an interim licence could be granted to Calgary Power and a serious power shortage could be avoided. The province's anxiety seems to have been fuelled, in large part, by information from Calgary Power. According to G.A. Gaherty, who was by then president of the company, energy consumption was on the rise in Alberta. Calgary Power produced 454,478,442 kilowatt hours in 1948, an 11 percent increase over the year before. Between 1946 and 1947, the company's peak load increased by 12,600 horsepower (hp), bringing it within 10,000 hp of the 125,000 hp limit that the company's plants could produce. ${ }^{66}$ Based on these figures, Gaherty concluded:

Only by starting the construction of the Spray plant immediately will it be possible to complete it in time to carry the peak load of $1950 \ldots$. . [T] he industrial, agricultural and business progress of Alberta, particularly central and southern Alberta and the City of Calgary, is dependent upon the construction of increased power

65 Armstrong, Evenden \& Nelles, supra note 18 at 143. In May 1948, Alberta’s Premier, Ernest Manning, wrote to MacKinnon about the need to exclude more land from Banff. Manning stated:

In order to carry out the intention of both Governments [with respect to the NRTA], therefore, a further slight revision in the Banff Park boundaries is necessary, involving an area of 19.4 square miles as indicated on the attached plan.... It will be obvious that such an amendment would be merely to give [e]ffect to the original intention and agreement of the two Governments, and would in no way affect or prejudice the Dominion's right to fix the flow of the Spray River in the Park for scenic purposes.

Letter from Ernest Manning to James A MacKinnon (21 May 1948), Edmonton, PAA (Manning Papers).

66 Memorandum from GA Gaherty to James A MacKinnon, "Memorandum Re Spray Power and Storage Project” (26 May 1948), Edmonton, PAC (RG 22, vol 238, file 33-4-10, pt 1) [Gaherty Memo]. 
facilities of which the Spray development is the base.... If it is not proceeded with, a very destructive power shortage and closing down of industry is in plain sight. ${ }^{67}$

In addition to being the Minister responsible for setting a minimum flow requirement for the Spray River, MacKinnon was also the (Liberal) Member of Parliament for Edmonton West. With his constituency in Alberta, the Minister had an added incentive to be responsive to the province's concerns about a power shortage. After receiving a letter from Premier Manning urging him to act quickly, MacKinnon wrote back and asked for Manning's own views on the Spray River flow requirement. ${ }^{68}$ MacKinnon wrote: "As the Park is located in the Province of Alberta, you have of course a particular interest in the maintenance of the amenities which it has to offer. It would, I think, be of assistance to me if you would indicate your views as to the degree to which we should allow water to be diverted from the Spray River." ${ }^{, 99}$ Manning delegated the task of recommending a minimum flow requirement to Russell, who promptly sent a telegram to MacKinnon suggesting a minimum flow requirement of $200 \mathrm{cfs} .{ }^{70}$ Russell did not include an explanation for his recommendation, but stated simply, "considering the value of the stream for power purposes any requirement above 200 second feet would be wasteful." ${ }^{71}$ A few days later, Russell wrote to Manning outlining his reasons for the recommendation. The letter suggests that Russell's recommendation was based largely on information that he had received from Calgary Power. Russell suggested that visitors to BNP would not be able to tell the difference between a 200 cfs flow and the Spray River in its natural state:

A characteristic of streams is that the rate of flow varies, not directly as the depth, but more nearly as the fourth or fifth power of the depth. That is to say, a small increase in depth greatly increases the velocity, and therefore, the volume. The following water level elevations of the Spray River recently recorded at Banff adequately show the conditions there.

Flow 150 second feet — the recorded depth is 4.14 feet

Flow 250 second feet - the recorded depth is 4.36 feet

Difference 0.22 feet

Flow 350 second feet - the recorded depth is 4.57 feet

Difference 0.21 feet

Ibid. Russell obtained a copy of this correspondence and transmitted it to MacMillan, Alberta's Minister in Charge of Water Resource and Irrigation, on 14 June 1948. Russell included a note to the effect that he agreed with Gaherty — that Spray Lakes Development had to be started immediately in order to carry the peak loads of 1950. See Letter from Ben Russell to DB MacMillan (14 June 1948), Calgary, ABEW (file 1552). The same correspondence must be have made its way to Premier Manning's office, as the Premier reiterated the same idea in a letter to MacKinnon, dated 18 June 1948. Manning wrote: “[T]he situation in the Province with regard to power is such that only by starting construction on the Spray development immediately, will it be possible to complete it in time to carry the peak load of 1950" (Letter from Ernest Manning to James A MacKinnon (18 June 1948), Calgary, ABEW (file 1552)). Letter from James A MacKinnon to EC Manning (12 June 1948), Edmonton, PAA (Manning Papers). Ibid.

Telegraph from Ben Russell to JA MacKinnon (18 June 1948), Ottawa, PAC (RG 22, vol 238, file, 33-410, pt 1).

Ibid. 
For each increase of 50 second feet then, the corresponding increase in depth is about one-tenth of a foot, an increase which is hardly perceptable even by those experienced to judge. ${ }^{72}$

Word for word, Gaherty had given the same explanation to MacKinnon in May 1948, less than a month before Russell wired his 200 cfs recommendation to Ottawa. ${ }^{73}$ Clearly, Russell had also been given Gaherty’s memorandum and was now using its arguments to justify his own recommendation to MacKinnon.

The second reason that Russell gave to Manning for recommending a $200 \mathrm{cfs}$ minimum flow was that a larger release would render the Spray Lakes Development uneconomical. Russell explained that in order to maintain a $200 \mathrm{cfs}$ flow at Banff over the 100-day tourist season (2 June to 10 September), 2,500 acre-feet of water would have to be released from the Spray Reservoir, the estimated value of which was $\$ 8,750$. Increasing the minimum flow to 250 cfs during the tourist season would require an additional 10,000 to 12,500 acre foot release, which would cost approximately $\$ 43,750$. Russell summarized: “Although the above calculations are approximate they serve to show the extravagance of endeavouring to improve the scenery at the expense of the power development." 74

Russell's economic argument echoes Gaherty's, except that Gaherty requested MacKinnon to implement a $180 \mathrm{cfs}$ minimum flow requirement. In support of this position, Gaherty explained that maintaining a flow of more than $150 \mathrm{cfs}$ (during the summer months) at the mouth of the Spray River would cause a serious loss of power. According to Gaherty, a requirement to maintain a $350 \mathrm{cfs}$ flow (as was contemplated by Minister Stewart in the late 1920s) "would at the outset mean a loss in production not far short of the annual consumption of two cities the size of the City of Lethbridge."75 Gaherty summarized: "It is therefore imperative that the release of water be kept down to what is demonstrably required adequately to preserve the scenic beauty of the Park." ${ }^{\text {,76 }}$

To sum up, after being asked for its input on a suitable minimum flow requirement for Spray River, the province responded just days later with a recommendation for $200 \mathrm{cfs}$. Judging by the correspondence of Russell, the director charged with formulating the recommendation, it appears that the province relied solely on the arguments of Calgary Power — namely, that it would be costly or wasteful to set the requirement any higher, and that tourists would not be able tell the difference between a $200 \mathrm{cfs}$ flow and the Spray River in its natural state.

MacKinnon also requested input from the CPR before fixing a flow requirement for the Spray River at Banff. ${ }^{77}$ As discussed above, the CPR had previously indicated to Minister

72 Letter from Ben Russell to EC Manning (18 June 1948), Ottawa, PAC (RG 22, vol 238, file, 33-4-10, pt 1) [Russell to Manning, 18 June 1948]. Roughly a year later, the entire letter was quoted before the federal Senate in the course of debate over whether to amend the National Parks Act. See Debates of the Senate of the Dominion of Canada, 20th Parl, 5th Sess (9 March 1949) at 145 [Senate Debate]. Gaherty Memo, supra note 66.

Russell to Manning, 18 June 1948, supra note 72.

Gaherty Memo, supra note 66 at 3.

Ibid.

Earlier in the spring of 1948, WA Mather, the President of CPR, wrote to James Allison Glen who was then the federal Minister of Mines and Resources, seeking an assurance that no decision would be made about the flow requirement without input from the CPR. Mather wrote: "Might I suggest that, having regard for the requirements of stream flow in respect of scenic attractions, fish protection and sanitation, 
Stewart that it would not accept a minimum flow of less than $350 \mathrm{cfs}$ during the tourist season. However, in June 1948, W.A. Mather, the President of the CPR, wrote to MacKinnon to say that his company would not object to minimum flow of $200 \mathrm{cfs}$ from June to the end of August (that is, slightly before the season's closing date of the Banff Springs Hotel) ${ }^{78}$ It would seem that the CPR altered its position in response to appeals and assurances provided by Calgary Power. Mather explained his company's position in the following terms in a telegram to MacKinnon:

[The] Power Company has now stated that because of effect upon winter storage, stipulation mentioned with respect to month of September will have effect impede project and after further consideration Canadian Pacific prepared waive stipulation so far as month of September is concerned, if Power Company is willing to make every reasonable attempt to provide for essential sewage and water supply requirements Banff Springs Hotel in September. ${ }^{79}$

After receiving this input from the province and the CPR, MacKinnon travelled to Alberta to meet with representatives from Calgary Power. During his visit, MacKinnon assured Calgary Power that he would set the minimum flow requirement for the Spray River at 200 cfs. This is revealed in a letter from Calgary Power's solicitor, Fraser A. Duncan, which thanked MacKinnon for all his “trouble and kindness” while in Banff, and relayed Gaherty’s delight. ${ }^{80}$ Duncan also suggested that MacKinnon should enter into an agreement with the Government of Alberta respecting the flow requirement and submitted a draft for his consideration. ${ }^{81}$ MacKinnon wrote to Manning in early September 1948, shortly after receiving Duncan's advice and draft, and informed the Premier of his intention to set a minimum flow requirement of 200 cfs for June, July, and August in the Spray River at its junction with the Bow River. $^{82}$

Thus, as of early September 1948, MacKinnon's mind was set as to the minimum flow requirement for the Spray River, so much so that he had told both Calgary Power and the province of his intention to formally establish a minimum requirement of $200 \mathrm{cfs}$ for the months of June, July, and August. MacKinnon had reached this conclusion on the basis of input of very few sources — the province, the CPR, and Calgary Power. Other parties tried to influence the Minister's decision, but their efforts met with little success.

One of the parties that did try was the Banff Advisory Council (the Council). In August, 1948, the Council wrote to the Superintendent of BNP, J.A. Hutchinson, to express its opposition to the Spray Lakes Development. ${ }^{83}$ The Council was concerned about the impacts that the development might have on stream flows and fish populations. In particular, the

this Company's officers be invited to consult with the Department's officers concerning the development which appears imminent”: Letter from WA Mather to James Allison Glen (8 April 1948), Ottawa, PAC (RG 22, vol 238, file 33-4-10, pt 1).

78 Telegraph from WA Mather to JA MacKinnon (22 June 1948), Ottawa, PAC (RG 22, vol 238, file 33-410, pt 1).

Ibid.

Letter from Fraser A Duncan to James A MacKinnon (31 August 1948), Ottawa, PAC (RG 22, vol 238, file 33-4-10, pt 1) [Duncan to MacKinnon, 31 August 1948].

Ibid. The draft agreement refers to the $200 \mathrm{cfs}$ minimum flow requirement.

Letter from James A MacKinnon to EC Manning (9 September 1948), Ottawa, PAC (RG 22, vol 238, file 33-4-10, pt 1).

83 Letter from REW Edwards, Secretary of the Banff Advisory Council, to JA Hutchinson (17 August 1948), Ottawa, PAC (RG 22, vol 238, file 33-4-10, pt 1). 
Council worried that reduced flows in the Spray River would create a fire hazard in BNP. In its view, "nothing could be more ruinous to the welfare of Banff than a forest fire of large proportions in the Spray Valley." ${ }^{\text {"4 }}$

The National Parks Association of Canada (the Association) was also deeply concerned about the Spray Lakes Development. ${ }^{85}$ The Association's Executive Secretary, Selby Walker, wrote to R.A. Gibson, Director in Charge of the National Parks Service, for information on the minimum flow requirement. ${ }^{86}$ Walker also wanted to know whether an official investigation had been conducted to determine the adequacy of a $200 \mathrm{cfs}$ minimum flow. He noted that the federal government had approved a project to increase the storage capacity of the Minnewanka Reservoir during the Second World War without any public consultation. Then, referring to the Spray Lakes Development, Walker stated: "There is no war time secrecy involved, and so the Spray River scheme should be thoroughly investigated.”87

The Parks Service itself also had objections to the Spray Lakes Development and the process used to select a minimum flow requirement. Hutchinson forwarded the letter that he had received from the Council to the Controller of the Parks Service in Ottawa and copied the Deputy Minister of Mines and Resources, H.L. Keenleyside. Along with the letter, Hutchinson included a note stating that the Council's points were important and should be taken seriously. ${ }^{88}$ Concerns also originated from higher up in the National Parks Service chain of command. Gibson, the Director of the Service, sent a memorandum to the Deputy Minister of Mines and Resources in September 1948, arguing that affected parties other than Calgary Power should be given an opportunity to express their views on the Spray Lakes Development and that a special commission should be appointed to hear those views. ${ }^{89}$

By early November 1948, it was clear to National Parks Service officials that the Spray Lakes Development would be built and that $200 \mathrm{cfs}$ would be set as the minimum flow requirement for the Spray River throughout most of the tourist season. This realization prompted Gibson to write another letter to the Deputy Minister, which he began by stating: "[A]ll officials concerned with national parks administration consider [the Spray Lakes]

\section{Ibid.}

See Reichwein, supra note 23 for background on the formation of the National Parks Association of Canada. In brief, the Association was formed in 1923 by members of the Alpine Club of Canada (ACC). Sir Arthur Oliver Wheeler, co-founder of the ACC, proposed that the ACC form the Association to defend the national parks system from commercial encroachment (ibid at 146).

Letter from Selby Walker to RA Gibson (15 November 1948), Ottawa, PAC (RG 22, vol 238, file 33-410, pt 1).

Ibid. MacKinnon responded to Walker's letter: “After exhaustive inquires and at the request of the interested parties I have set the minimum flow that must be maintained at the mouth of the Spray River at 200 c.f.s. during the holiday season. It is our resolve that the attractiveness of the Spray valley will not be interfered with by the development of the Spray Lakes power project by the Calgary Power Company” (Letter from JA MacKinnon to Selby Walker (22 November 1948), Ottawa, PAC (RG 22, vol 238, file 33-4-10, pt 1)). As to Walker's question about whether there had been an investigation into the adequacy of a 200 cfs requirement, MacKinnon replied: “The Alberta Government maintain that a flow of 200 c.f.s. at its mouth, after investigations by their engineers, would be sufficient to maintain the attractiveness of the Spray River, and the Canadian Pacific Railway agreed to this” (ibid).

Letter from JA Hutchinson to HL Keenleyside (18 August 1948), Ottawa, PAC (RG 22, vol 238, file 33-4-10, pt 1).

Letter from RA Gibson to HL Keenleyside (13 September 1948), Ottawa, PAC (RG 22, vol 238, File 33-4-10, pt 1). Gibson goes on to accuse Calgary Power of working to exclude other voices from the debate: "Apparently it is the desire of the Company that the argument on this question should be limited to the Company and the Departmental officials and the Company through every means at its disposal is endeavouring to have this matter dealt with as an emergency" (ibid). 
scheme, as now proposed, a violation of the spirit and intent of Section 4 of the National Parks Act." ${ }^{\text {90 }}$ Despite his frustrations with the lack of public consultation, and his concerns about impacts of the development on BNP, Gibson felt that the National Parks Service still had a responsibility to recommend actions that would afford some protection to the park. ${ }^{91}$ In Gibson's view, this meant ensuring that either the federal or provincial government could re-open the Spray River flow requirement if it should turn out that Calgary Power's "representations about the flow necessary to protect the park scenery [were] erroneous." 92 As a possible basis for reopening discussions, Gibson suggested including in the preamble of an agreement between the Dominion and the province a summary of the facts justifying a $200 \mathrm{cfs}$ minimum flow requirement, including evidence to the effect that $200 \mathrm{cfs}$ would adequately preserve the scenic beauty of the park. ${ }^{93}$

As mentioned above, MacKinnon, by and large, overlooked the concerns and recommendations voiced by the National Parks Service and groups such as the Banff Advisory Council and the National Parks Association of Canada. However, there was one concern that the Minister took to heart - that Calgary Power's proposed plan may not have provided for contingencies such as extremely dry years and forest fires. Hence, in his meeting with Calgary Power in summer of 1948, the Minister asked Calgary Power to increase the storage capacity of the proposed reservoir in order to store extra water to be released in case of an emergency. ${ }^{94}$ Calgary Power agreed to the increase when MacKinnon was in Alberta. ${ }^{95}$ Then in mid-September 1948, Gaherty sent MacKinnon a letter on the increased storage. ${ }^{96}$ In short, the company would provide an additional 20,000 acre-feet of storage and release the water when directed to do so by the Minister. ${ }^{97}$ Gaherty's letter suggested that fish were an intended primary beneficiary of the increased storage. He commented: "While sports fishing does not fall within the scope of the legislation relating to the fixing of the flow of the Spray river, the Company is anxious to do what it can to reassure those interested in fishing that no detriment will result from the Spray development." ${ }^{98}$ After noting some of the advantages of the Spray Lakes Reservoir from the

Letter from RA Gibson to HL Keenleyside (3 November 1948), Ottawa, PAC (RG 22, vol 238, file 33-410, pt 1). Section 4 of the National Parks Act is quoted above, supra note 39 and accompanying text. Letter from RA Gibson to HL Keenleyside, ibid.

Ibid.

Ibid.

JM Wardle, Director of the Special Projects Branch of Mines and Resources, investigated this possibility earlier in the summer of 1948. Wardle wrote to Deputy Minister of Mines and Resources on 16 July 1948, suggesting that capacity of the reservoir should be increased to 200,000 acre-feet. Wardle stated: "It is quite true that it would not be possible to store 200,000 acre-feet every year but any extra storage that could be obtained over and above 160,000 acre-feet in any year would be extremely useful in subsequent years of reduced run-off": Letter from JM Wardle to HL Keenleyside (16 July 1948), Ottawa, PAC (RG 22, vol 238, file 33-4-10, pt 1).

$95 \quad$ Duncan to MacKinnon, 31 August 1948, supra note 80.

96 Letter from GA Gaherty to JA MacKinnon (15 September 1948), Calgary, ABEW (file 1552) [Increased Storage Letter].

97 Ibid. Gaherty writes:

In practice, such excess would be computed by deducting the water in storage at the beginning of the season from the water in storage at the end of the season. To the extent of such credit the Company would release water as required from time to time by the Minister from such purposes at a rate not to exceed the 100 cu.ft. per second for which outlet works are being provided in the main dam; such credit being reduced by any water so released and also any water the C.P.R. may require during September. The Company will fulfill the above requirement when called upon by the Minister to do so, but must be free to operate the power development and the reservoir as it may see fit, and in particular at all times to generate any such energy as it may require and to draw down the reservoir to the extent it may deem advisable. Ibid. 
perspective of anglers (for example, the possibility of lake-fishing, and a "reduction in the peak flow on the lower Spray which tends to wash fish downstream"99), Gaherty acknowledged a potential downside of the project, which the additional storage would help to address - that there may be times when the run-off into the Spray River (below the dam site) might be insufficient to maintain surface flows in certain reaches of the river. ${ }^{100}$ Today, as we will discuss later, we might refer to this sort of proposal as a water bank, which creates an account which might be drawn upon to provide a variety of environmental services.

The essential elements of the Spray River flow requirement were, thus, settled by the end of 1948. In the early part of 1949, the parties exchanged correspondence confirming the deal that had been struck. In January 1949, MacKinnon wrote to Alberta’s Minister of Water Resources and Irrigation, David Ure, to say that he would set the Spray River minimum flow requirement at $200 \mathrm{cfs}$ (as he had previously said was his intention), provided that the province include three conditions in any licence granted to develop the Spray Lakes Valley. ${ }^{101}$ The first condition was that the licensee would have to meet the prescribed minimum flow requirement. The second condition, which spoke to the agreement worked out between Calgary Power and the CPR, was that the licensee would have to supply water to the Banff Springs Hotel for its sewage and water supply needs every September. Finally, for the purposes of fire control, the licensee would have to build a valve into its storage works such that water could be discharged into the Spray River at a rate of $100 \mathrm{cfs} .^{102}$ Also in his letter to Ure, MacKinnon went on express his desire "to reassure those interested in fishing that no detriment will result from the Spray development."103 MacKinnon then went on to reproduce the entirety of Gaherty's Increased Storage Letter, as if its contents were his own thoughts, and concluded with: "I understand that the licensee will provide you with an assurance that it will provide the additional 20,000 acre feet of storage subject to the conditions above set forth." 104

Ure wrote to MacKinnon twice in early February 1949. In his first letter he expressed his willingness to include the conditions as set out by MacKinnon in any licence issued to Calgary Power for the development of the Spray Lakes Project. ${ }^{105}$ In the second letter, Ure wrote to say that he had received an assurance from Calgary Power "covering the provision for some water for fishing and any emergency that may arise.”106

By the spring of 1949, all that was required in order for the province to issue an interim licence to Calgary Power was an amendment to the National Parks Act. That process got underway when Calgary-based Senator George Henry Ross introduced a bill to amend the National Parks Act. ${ }^{107}$ Ross outlined a number of reasons in support of the Bill during the

\footnotetext{
$99 \quad$ Ibid.

100 Ibid. Gaherty added: "Whether or not this is so and what the effect on the fishing might be can only be determined after the works are completed."

101 Letter from James A MacKinnon to David A Ure (25 January 1949), Ottawa, PAC (RG 22, vol 238, file 33-4-10, pt 1).

Ibid.

Ibid.

Ibid.

Letter from DA Ure to James A MacKinnon (9 February 1949), Ottawa, PAC (RG 22, vol 238, file 33-410, pt 1).

106 Letter from DA Ure to James A MacKinnon (10 February 1949), Ottawa, PAC (RG 22, vol 238, file 334-10, pt 1).

Bill O-2, An Act to amend the National Parks Act, 5th Sess, 20th Parl, 1949.
} 
second reading in March 1949. The Senator emphasized that Alberta required more power to maintain its economic growth, and that the project would help to reduce flooding near Calgary. ${ }^{108}$ As for the potential impacts of the development on BNP, the Senator pointed out that Calgary Power had already made commitments to protect park scenery (that is, the licence conditions stipulated by MacKinnon). Ross argued that the impacts to BNP would be minimal. In particular, he noted that "[a]long the 23 miles between the proposed dam and the confluence of the Spray and Bow rivers there are no waterfalls, no cascades or other noteworthy features."109 Moreover, even if 54 square $\mathrm{km}$ were removed from the park, another 6,683 square km remained. ${ }^{110}$ The Senator also raised the possibility of benefits for anglers, quoting the City Commissioner of Calgary:

By controlling the flow of water in the Spray river, this is one of the recognized methods of improving fishing in mountain or flood streams. The violent flooding of the streams scours the bottoms and washes the fish down to larger rivers, whereas if the Spray river were controlled there could be ponds and pools constructed which would be of the same size during the spawning season as during the fishing season. ${ }^{111}$

Ross's arguments did not go over well with some of the other senators, particularly Senator T.A. Crerar, the former Minister of Mines and Resources. Crerar regarded the proposed Bill as a violation of the purpose of the National Parks Act. ${ }^{112}$ He was also skeptical of the claim that a $200 \mathrm{cfs}$ minimum flow would adequately protect the river's scenic beauty and actually improve the river for fishing, as was suggested by Ross. Crerar concluded his remarks by expressing the hope that the Bill would be carefully scrutinized by the Senate's Natural Resources Committee (the Senate Committee), which he headed, and that the Bill would pass "only ... on condition that the flow per second be raised to something substantial enough to ensure that at all times the Spray River will be the really scenic stream it always has been, and not a mere procession of bare rocks with water skirting around them.”113

The Senate Committee met immediately following the Bill's second reading. Fraser Duncan, Calgary Power's solicitor, travelled to Ottawa to attend the debates on amending the National Parks Act. After learning that the Bill had been referred to the Senate Committee, Duncan wired Russell in Alberta to inform him of the development. Ure then sent a wire to Ottawa, authorizing both Duncan and Gaherty to represent Alberta before the Senate Committee. ${ }^{114}$ Just before the start of the Senate Committee meeting, Duncan advised MacKinnon of Crerar's "strong speech” against the Bill in the Senate Chamber. ${ }^{115}$ This

Senate Debate, supra note 72 at 146.

Ibid.

Ibid at 145 .

Ibid at 146 .

Ibid at 147.

Ibid. Perhaps to avert allegations of hypocrisy, Crerar also addressed the fact that he recommended legislation to increase the height of the dam at Lake Minnewanka during his term as Minister of Mines and Resources in the mid-1940s. The Senator explained that his recommendation was made during the war, and "solely on the basis of the urgent need of explosives for use in the war" (ibid). Albeit necessary, the result was still a sad one in the Senator's eyes, "for it resulted in a change in beautiful Lake Minnewanka. At a certain period of the year the shores of that lake are a huge mud flat; its natural scenic beauty has been largely destroyed, now and for all time to come” (ibid).

Telegraph from DA Ure to Fraser Duncan (8 March 1949), Edmonton, PAA (accession GR1972. 0302/341, box 7).

Letter from Fraser Duncan to David A Ure (10 March 1949), Edmonton, PAA (accession GR1972.0302/341, box 7). 
prompted MacKinnon to walk in on the Senate Committee meeting and seek permission to speak. MacKinnon's words had the "desired effect," according to Duncan. The following day, Crerar presented the Senate Committee's report, which recommended that the Bill should pass without any amendments. ${ }^{116}$ The Bill then moved swiftly through the House of Commons.

\section{Final Steps at the Provincial LeVel}

After Parliament amended the National Parks Act, Alberta's Lieutenant Governor in Council approved two Orders in Council to secure Calgary Power's water rights against possible future applications under section 10 of the WRA. First, on 4 May 1949, pursuant to section 10(7) of the WRA, the Lieutenant Governor approved an Order in Council (OIC) reserving all the waters of the Spray River and Smith Dorrian Creek and their tributaries. ${ }^{117}$ Then, on the same day, the Lieutenant Governor approved another OIC, this one authorizing the Minister to grant an interim licence to Calgary Power that would allocate to the company the above-mentioned reserved waters, subject to the terms and conditions set forth in an annexed schedule - Schedule A (which formed the company’s interim licence) ${ }^{118}$ The same OIC authorized the Minister in charge of the WRA to enter into an agreement with Calgary Power to develop the Bearspaw Site. Two days later, on 6 May 1949, Minister Ure and H.B. Sherman, the Vice-President and General Manager of Calgary Power, signed the Bearspaw agreement. Ure issued Calgary Power its interim licence on the same day. ${ }^{119}$

\section{EFFORTS TO RESTORE THE SPRAY RIVER'S AQUATIC ECOSYSTEM: 1975-1981}

The construction of the Spray Lakes Reservoir changed the Spray Lakes Valley in a number of ways. The Spray Lakes themselves have disappeared, buried under about $60 \mathrm{~m}$ of water, along with Buller Creek, Woods Creek, the Spray Falls, and the cutthroat trout spawning grounds associated with those sites. ${ }^{120}$ The Canyon Dam stands as a permanent barrier between the Spray River and the reservoir. In order to meet the $200 \mathrm{cfs}$ flow requirement set out in its interim licence, Calgary Power elected to release water down Goat Creek, at the north end of the Spray Lakes Reservoir, rather than through the Canyon Dam. This resulted in extremely low surface flows in the stretch of the Spray River immediately below the Canyon Dam. The use of Goat Creek for releases came as a surprise to parties other than Calgary Power, who believed that the Canyon Dam would be used to augment the Spray River flows during the summer months. ${ }^{121}$ This belief may have been based on the fact that Calgary Power had agreed, as a term of its interim licence, to build a valve capable of discharging 100 cfs through the Canyon Dam. ${ }^{122}$ It may also be the case that information

$116 \quad$ Ibid

117 OIC 546/49, (1949) A Gaz, 570.

118 OIC 547/49 (1949), Edmonton, PAA (Accession GR 1970.0427). Interim Licence, supra note 63.

119 Memorandum of Agreement, supra note 55.

120 Schindler \& Pacas, supra note 3 at 5-21. It should be noted here that while the Spray Lakes Reservoir destroyed important cutthroat trout habitat, it now supports an excellent lake trout fishery. See Mitchell \& Prepas, supra note 1.

121 Dwight R Mudry \& Roderick B Green, Fisheries Investigations on the Spray River, Banff National Park, 1975-1976 (31 March 1976) at 41-42 [unpublished, archived at Banff National Park Wardens’ Office].

122 Ibid at 41. Calgary Power's obligation to build the valve is clause 16(b) of its Interim Licence, supra note 63. 
provided by the company led others to believe that it intended to release water directly into the Spray River at the Canyon Dam in order to meet the minimum flow requirements at the confluence with the Bow. ${ }^{123}$

For many years after the construction of the Spray Reservoir, Parks Canada dealt with declining fish populations in the Spray River by introducing large numbers of fish, including non-native species such as brook and rainbow trout. ${ }^{124}$ Then in the mid-1970s, the agency began to think seriously about reviving the river's native fish populations and hired biologists Dwight Mudry and Roderick Green to gather information and recommend ways of improving the native fish habitat. ${ }^{125}$ Mudry and Green conducted their investigations from 1975 to 1976 , and concluded that the construction of the Spray Reservoir had resulted in permanent changes to the ecology of the Spray River and its tributaries; however, steps could be taken to increase native fish populations. The biologists' key recommendation was for a small, constant flow of 5 cfs to be released from the Canyon Dam on a year-round basis. The two admitted to selecting a 5 cfs flow "in a somewhat arbitrary manner," 126 but justified the figure on the basis that it would allow sufficient winter flow without lowering water temperatures too much in the summer. ${ }^{127}$

Soon after Parks Canada received Mudry and Green's report, the agency turned to the province for help in convincing Calgary Power to modify the Spray River flow regime. Representatives from Alberta Environment and Parks Canada met in August 1976 and agreed to engage Calgary Power in negotiations as soon as possible. ${ }^{128}$ However, it was not until late 1979 that Alberta Environment petitioned Calgary Power for a constant release from the Canyon Dam.

The long lapse of time between Parks Canada's decision to take action and Calgary Power actually receiving a request was due, in part, to bureaucratic formality and, in part, to some

For example, when Miller and MacDonald conducted their study of Spray Lakes Valley fishery habitat in 1949 they based all of their assumptions regarding the future state of the Spray River on the notion that water would be released directly into the Spray River from Canyon Dam during the summer months. In order to prepare their report, the scientists consulted with officials from Calgary Power, both in Calgary and at the dam site: Miller \& McDonald, supra note 12 at 1 .

124 Mudry \& Green, supra note 121, note that brook trout tend to out-compete cutthroat trout because their young hatch earlier in the season than cutthroat trout, giving brook trout a size advantage. The scientists observed the effects of the introduction of brook trout in the Spray River, commenting: "The introduced brook trout population appears to have effectively displaced any native species which were in the lower reaches and form a significant portion of the fish population in the upper reaches" (ibid at 42).

It is unclear why Parks Canada decided to try restoring native fish habitat in the Spray River at this time. The decision may have been prompted by a 1974 report, written by biologists from Alberta's Fish and Wildlife Division: GE Thompson \& AP Wiebe, Impact of the Spray Canal Failure on Goat Creek, Alberta (1974) [unpublished, archived at Edmonton, PAA, (Accession GR 1991.0100, file S53-B)]. The report was written after the Spray Canal failed on 19 December 1972, spilling about 3000-3500 acre-feet of water with peak instantaneous flows of $6400 \mathrm{cfs}$ into Goat Creek. Following the incident, Calgary Power agreed to pay Alberta's Fish and Wildlife Division to assess the impacts on fishery resources. In their report, Thompson and Wiebe concluded that it was impossible to differentiate between the damage caused by the 1972 flood and the damage caused by flow regulation prior to the incident (ibid at 35). The biologists recommended a review of the flow regulation in the Spray River Watershed, efforts to approximate seasonal flows in Goat Creek, and an investigation into the possibilities of flow augmentation by passing water over or through Canyon Dam directly into the Spray River (ibid at 3537).

$126 \quad$ Mudry \& Green, supra note 121 at 40.

127 The scientists made additional recommendations, including no further introductions of brook trout (ibid at 43) and a $5 \mathrm{cfs}$ release down Goat Creek on a year-round basis (ibid at 40).

128 Memo to File, J Kilistoff, Aquatic Resource Manager, Parks Canada, Banff National Park (15 September 1976), Calgary, ABEW (file 1552). 
foot-dragging. In early November 1976, Alberta Environment decided that the Minister responsible for Parks Canada should write to Alberta's Minister of the Environment and formally request assistance in negotiating with Calgary Power. Alberta Environment said nothing about the need for this correspondence to Parks Canada until the spring of 1978, such that the whole matter was effectively put on hold for a year and a half. ${ }^{129}$

Officials from Alberta Environment, Environment Canada, Parks Canada, and BNP met in February 1979 to "identify and establish [the] courses of action that [had] to be taken by [their] respective agencies preparatory to the Province of Alberta entering into negotiations with Calgary Power." ${ }^{130}$ In the course of this meeting, the attendees reached the following conclusion:

In light of the conditions set forth in the exchange of correspondence (January 25, 1949 and February 10, 1949) between the Honourable James A. MacKinnan, Minister of Mines and Resources, Ottawa and the Honourable David A. Ure, Minister of Water Resources and Irrigation, Province of Alberta; and from the President, Calgary Power to the Honourable David A. Ure (letter of February 7, 1949), there are grounds for renegotiating waterflow rates for the purpose of re-habilitating the fish habitats of the Spray River and Goat Creek systems. $^{131}$

Unfortunately, the memo summarizing the February 1979 meeting does not indicate which conditions the attendees saw as grounds for renegotiating flow rates. However, a report written later that year provides some further insight. ${ }^{132}$

Following the meeting, Parks Canada decided to gather more information on the amount of flow necessary to restore the native fish habitat in the Spray River. This decision may have stemmed from the determination that there were grounds for renegotiation with Calgary Power - that is, the meeting with officials from Alberta Environment and Environment Canada may have convinced Parks Canada that it was entitled to insist on a greater release into the Spray River (beyond the 5 cfs recommended by Mudry and Green). Alternatively, Parks Canada may simply have wanted to be certain that any request that was put to Calgary Power on its behalf would, if acceded to by the company, result in a release from the Canyon Dam sufficient to revive native fish populations. In either case, Parks Canada's desire for more information led to the creation of the Spray River Study Team. The team consisted of officials from the two branches of Environment Canada — the Inland Waters Directorate and the Canadian Wildlife Service — as well as officials from Parks Canada. J.T. Moenig, an official from the Inland Waters Directorate, headed the team.

In April 1978, the Regional Administrator of Alberta Environment, RJ Hilton, sent a letter to the Western Regional Office of Parks Canada in which he apologized for the delay in transmitting information to Parks Canada, and calling it "a misunderstanding by myself within our Department”: Letter from RJ Hilton to Joe Kersoff, Director, Western Region, Parks Canada (6 April 1978), Calgary, ABEW (file 1552). 1979), Calgary, ABEW (file 1552).

Ibid.

JT Moenig, Canyon Dam Flow Release Recommendations Based on Instream Fishery Needs (1979) [unpublished, archived at Calgary, ABEW; on file with author]. 
The outcome of the Spray River Study Team's work was the report Canyon Dam Flow Release Recommendations Based on Instream Fishery Needs. ${ }^{133}$ This report provided some insight into the "grounds for renegotiating water flow rates," identified by attendees of the February 1979 meeting. Moenig noted in the introduction to the report that "[i]t was understood, but not incorporated into the Licence” that Calgary Power would maintain 20,000 acre-feet of storage "for downstream fishery maintenance, sewage dilution and water supply at the Banff Springs Hotel, firefighting and any other emergencies which might arise.” ${ }^{134}$ Moenig went on to point out that Calgary Power was required to install a valve in the Canyon Dam to enable releases upon request from Parks Canada; however, "[r]equests for additional release were never forthcoming from Parks Canada and the valve [had] since fallen into disrepair." 135 By highlighting the fact that Parks Canada never took advantage of the 20,000 acre-feet reserved for its benefit, and that Calgary Power had allowed the Canyon Dam valve to fall into disrepair, Moenig may have been pointing out reasons why Parks Canada was entitled to some accommodation from Calgary Power regarding Spray River flows.

The Spray River Study Team's key recommendation was for a constant, year-round release of $15 \mathrm{cfs}$ into the Spray River at the Canyon Dam. As the title of the report suggests, the team considered the science of instream flow needs in formulating this recommendation, including Donald Tennant's study, which suggested that local fisheries were at a high risk for severe degradation when projects such as dams reduce stream flows to less than 30 percent of their pre-project flows. ${ }^{136}$ The team was also intent on simply avoiding the worst problems of the current flow regime, such as dry stretches below Canyon Dam and marginal winter habitat. This appears from their overall justification for the $15 \mathrm{cfs}$ release recommendation:

A constant release of $15 \mathrm{cfs}(0.43 \mathrm{~m} 3 / \mathrm{sec})$ would achieve a more balanced flow regime avoiding almost negligible flows below the Canyon Dam during various periods of the year. Winter flows would be a minimum of $15 \mathrm{cfs}(0.43 \mathrm{~m} 3 / \mathrm{sec})$ which should be sufficient as maintenance flows for over-wintering fish and provide better water quality during low flow periods especially during late winter. ${ }^{137}$

In the end, the Spray River Study Team's report and the $15 \mathrm{cfs}$ release recommendation provided Parks Canada with the information necessary to initiate serious negotiations between Calgary Power and Alberta Environment (acting on Parks Canada’s behalf).

In October 1979, the federal Minister of the Environment, John A. Fraser, wrote to Alberta's Minister of the Environment, J.W. Cookson, asking his department to approach Calgary Power and begin the process of renegotiating the terms of the Spray licence. ${ }^{138}$ Along with a constant release of 15 cfs into the Spray River at Canyon Dam, Fraser asked

133 Ibid.

$134 \quad$ Ibid at 2.

135 Ibid.

$136 \quad$ Ibid at 11, citing Donald Leroy Tennant, "Instream Flow Regimens for Fish, Wildlife, Recreation and Related Environmental Resources” (1976) 1:4 Fisheries 6. Moenig notes that flows below the Canyon Dam represented on average less than 25 percent of pre-project flows at the time when the team conducted its investigations: Moenig, ibid at 12. 
Alberta Environment to pursue three additional commitments from Calgary Power: (1) a way to gauge the discharge at Canyon Dam; (2) a promise not to exceed a maximum instantaneous flow of $30 \mathrm{cfs}$ at the Canyon Dam; and (3) the elimination of large and sudden discharges of water down Goat Creek. ${ }^{139}$ Fraser also explained that Parks Canada would "waive certain provisions of the existing licence, as well as certain understandings which have developed through correspondence between previous Ministers and Mr. G.A. Gaherty” ${ }^{140}$ in order to expedite an agreement with Calgary Power. In particular, Parks Canada would waive the requirement to maintain a flow of $200 \mathrm{cfs}$ at the Spray/Bow confluence in June, July, and August. ${ }^{141}$ Neither would Calgary Power be required to maintain 20,000 acre-feet of additional storage, or a valve capable of discharging water at the rate of $100 \mathrm{cfs}$ at Canyon Dam. Fraser did not mention the fact that Calgary Power had not been compliant with the latter requirement (that is, the valve at the Canyon Dam had fallen into disrepair) for years. However, he included with his letter copies of correspondence from 1949 - between Ministers Ure and MacKinnon and between Gaherty and Ure - for the stated purpose of "justify[ing] renegotiation of the terms of the agreement with Calgary Power." 142 Parks Canada may have wanted to draw attention to this correspondence (and the commitments included therein) to show that Calgary Power had been non-compliant with the terms of its licence, but perhaps also to draw attention to the fishery concerns.

Alberta Environment conveyed the contents of Fraser's letter to Calgary Power in November $1979 .{ }^{143}$ The company considered Parks Canada's request and agreed in May 1980 to maintain a continuous release of $15 \mathrm{cfs}$ at the Canyon Dam. ${ }^{144}$ Significantly, the new scheme proposed by Parks Canada involved releasing less water from the Spray Lakes Reservoir on an annual basis (that is, the amount of water that had to be released to maintain a 200 cfs flow in June, July, and August exceeded the amount needed to maintain a continuous 15 cfs release at the Canyon Dam). ${ }^{145}$ In order to implement the scheme, Calgary Power worked for several months to rehabilitate a diversion tunnel at the Canyon Dam. Water began flowing from the Spray Lakes Reservoir directly into the Spray River in the summer of 1981 — the same year that Calgary Power changed its name to TransAlta. ${ }^{146}$ TransAlta's water licence has never been amended to reflect the new arrangement. The

\footnotetext{
139 Ibid.

$140 \quad$ Ibid.

141 Ibid. Fraser added: “As you may know, the C.P.R. Banff Springs Hotel is now receiving its essential water and sewage disposal services from the Banff townsite.”

142 Ibid.

143 Letter from Harold Cameron, Hydro Electric Supervisor, Alberta Environment to W Saponja, Director of Power Production, Calgary Power (1 November 1979), Calgary, ABEW (file 1552-A). Letter from RA Keys, Manager of Hydro Operations, Calgary Power to HP Cameron (2 May 1980), Calgary, ABEW (file 1552-A).

145 Interview of Roger Drury, Senior Technical Specialist, TransAlta by Sarah Nykolaishen (5 October 2011) [Drury Interview].

146 While the correspondence indicates that TransAlta agreed to maintain a continuous release of $15 \mathrm{cfs}$ at Canyon Dam, it seems that in practice the release has been somewhere between 7 and 9 cfs. Eaton, supra note 10 at 8-10, writes that the Spray River downstream of the Spray Lakes Reservoir receives a regulated release of about $8.8 \mathrm{cfs}$. In 1999, TransAlta conducted maintenance activities at Canyon Dam that required shutting off the flow from the reservoir to the Spray River. TransAlta hired Golder Associates Ltd to monitor flows in the Lower Spray Basin during the maintenance work and conduct fish salvage operations. Golder prepared a report in connection with its monitoring which states that the typical summer discharge from the Canyon Dam is $7 \mathrm{cfs}$ (see Memorandum from Golder Associates Ltd to TransAlta, "Final Report: Flow monitoring and fish salvage operations associated with maintenance shut down of the Canyon Dam” (September 1999) [on file with authors]).
} 
province issued the company a consolidated licence in 1998 that contains the same conditions in relation to the Spray River as Calgary Power's original 1949 interim licence. ${ }^{147}$

\section{LATER EFFORTS TO RESTORE THE SPRAY RIVER'S AQUATIC ECOSYSTEM: 1996-PRESENT}

Visitor use of the national parks grew steadily throughout the period when Parks Canada, Alberta Environment, and Calgary Power contemplated a continuous release from the Canyon Dam. In 1976-77, Parks Canada recorded more than 16.7 million visits to the national parks. Ten years earlier, this number was less than 10 million. ${ }^{148}$ This growing pressure on park resources caused many to re-evaluate the purpose of national parks or to question whether the twin goals of section 4 of the National Parks Act were truly compatible — that is, promoting visitor enjoyment and ensuring that the parks would be left unimpaired for the enjoyment of future generations. ${ }^{149}$ For many, the paramount goal of parks management should be "ecological integrity," or ensuring that natural systems can survive changes and function at optimum capacity. ${ }^{150}$ Parks Canada introduced ecological integrity into national parks policy in 1979, stating: "Ecological and historical integrity are Parks Canada's first considerations and must be regarded as prerequisites to use."151 In 1988, Parliament legislated the maintenance of ecological integrity as the first priority in national park zoning and visitor use management. ${ }^{152}$

Unfortunately, incorporating the concept of ecological integrity into national parks policy and legislation did little to alleviate the pressures of visitor use and commercial development on the parks' natural systems. In response to public concerns and ongoing threats to the ecological integrity of BNP, the Minister of Canadian Heritage commissioned a two-year study of the Banff-Bow Valley in 1994. The study focused on the Bow River watershed, from the headwaters of the river near Bow Lake to the Banff East Gate - approximately 53 percent of Banff National Park. ${ }^{153}$ A Task Force of five independent experts with expertise in ecological sciences, tourism, public policy, and management led the study.

The Task Force submitted its summary report to the Minister in October $1996 .{ }^{154}$ The report opened with a number of sobering conclusions regarding the state of BNP. The Task Force found that BNP's ecological integrity had been compromised over the years by park management, human use, development, and the highway and railway passing through the

Licence for the Development of Water Power at the Spray Power and Storage Development, Priority No. 1948-05-14-02 (26 May 1998) at s 8 [on file with authors]. Roger Drury notes that the province has never required an amendment to the Spray licence to reflect the 1980 agreement with Alberta Environment. Moreover, the company would be unlikely to request such an amendment, that could trigger a broader environmental review (Drury Interview, supra note 145).

H Ian Rounthwaite, “The National Parks of Canada: An Endangered Species?” (1982) 46:1 Sask L Rev 43 at 43.

Ibid at 50.

See Fluker, supra note 27, for an overview of the rise and development of the concept of ecological integrity.

Parks Canada, Parks Canada Policy (Ottawa: Ministry of the Environment, 1980) at 12.

An Act to amend the National Parks Act, RSC 1985, c 39 (4th Supp), s 5(1.2), amending RSC 1985, c $\mathrm{N}-14$.

JR Brent Ritchie, "Managing the Human Presence in Ecologically Sensitive Tourism Destinations: Insights from the Banff-Bow Valley Study" (1998) 6:4 Journal of Sustainable Tourism 293 at 294.

Banff-Bow Valley Task Force, Banff-Bow Valley: At the Crossroads - Summary Report (Banff: Ministry of Supply and Services Canada, 1996) [Banff-Bow Valley Study]. 
park. ${ }^{155}$ The Task Force also found that serious and irreversible harm would result unless there were to be a reduction in the rate of development inside the park and contiguous areas and in visitor numbers. ${ }^{156}$

The Ecological Outlook Project, a cumulative environmental assessment of the Banff-Bow Valley, informed the Task Force's conclusions and recommendations on environmental integrity. ${ }^{157}$ One contribution to the Ecological Outlook Project by David Schindler and Charlie Pacas focused specifically on the cumulative effects of human activity on the valley's aquatic ecosystems. ${ }^{158}$ Schindler and Pacas examined several major impacts on the valley's aquatic ecosystems, including power reservoirs and dams. Schindler and Pacas noted that several reservoirs have impacted BNP’s aquatic ecosystem, including Lake Minnewanka, the Lower Kananaskis Reservoir (built in 1913), the Barrier Reservoir (built in 1947), and, of course, the Spray Lakes Reservoir. The authors wrote: "[T]hese reservoirs have had a devastating effect on a once-important fishery for various native salmonid species, including cutthroat trout and bull trout." ${ }^{159}$ The authors recommended restoring natural water levels and flow patterns wherever possible, adding that, "[i]n particular, natural flows should be returned to the Spray and Cascade rivers, in order to restore damaged aquatic and riparian habitats."160

The Task Force submitted more than 500 recommendations to the Minister, many of them based on the findings of the Ecological Outlooks Project. The Task Force made two recommendations in relation to the Spray River: to reintroduce cutthroat into the river and to encourage TransAlta and the Province of Alberta to "assess options for restoring more natural water flows in the Spray River by modifying releases from the Spray Reservoir.”161 These recommendations reflected the fact that cutthroat trout had not recovered in the Spray River below the Canyon Dam, despite the continuous release through the Canyon Dam.

The Banff-Bow Valley Study was part of an ongoing process of formal assessments by the federal government to prepare and revise park management plans. ${ }^{162}$ The first BNP Management Plan was tabled in Parliament in 1988 and was to be reviewed in 1993. Parks Canada and BNP officials approved a revised management plan in 1997, which incorporated many of the recommendations of the Banff-Bow Valley Study. ${ }^{163}$

The 1997 BNP management plan identified several major concerns related to the park's aquatic ecosystems, one of which was the amount of water released from the Spray Lakes Reservoir into the Spray River. The plan noted that decreased flows in the Spray River have altered its physical structure, as well as its riparian and aquatic systems. ${ }^{164}$ To address these issues, the plan recommended that Parks Canada work with TransAlta to restore a more

Ibid at 14.

Ibid.

Ritchie, supra note 153 at 296.

Schlinder \& Pacas, supra note 3.

Ibid at 5-7.

Ibid at 5-52.

Banff-Bow Valley Study, supra note 154 at 43.

Ritchie, supra note 153 at 294.

Environment Canada, Banff National Park: Management Plan July 2007 Amendment (Ottawa: Parks Canada, 1997), online: Parks Canada <www.pc.gc.ca/ /media/pn-np/ab/banff/plan/pdf/plan1_e.ashx>. Ibid at 17. 
natural flow regime in the river. ${ }^{165}$ The management plan did not indicate whether Parks Canada should attempt to involve the province in negotiations with TransAlta as it had in the past.

Parks Canada did not take any major steps towards improving the state of the Spray River until 2002, when it provided funding for a two-year research project on restoration options. TransAlta also provided funding for this research. The project researcher, Peter Eaton, measured various aspects of the river, including discharge, temperature, fish community, and riparian vegetation. Eaton then compared the measurements to habitat suitability indices in order to determine the quality of cutthroat trout and bull trout habitat in the river. Eaton found that stream flows and water depths were primary limiting factors for the reestablishment of native fish species in the Spray River. More precisely, stream flows were insufficient to create the deep pools that adult cutthroat trout and bull trout need to thrive. ${ }^{166}$ Eaton concluded that "significantly greater stream flows and the elimination of non-native fish species" 167 would be necessary to restore long-term ecological integrity in the Spray River. Unlike those who had studied the Spray River before him, Eaton did not try to prescribe an exact rate at which water should be released into the river from the Spray Lakes Reservoir. Instead, Eaton suggested that the effects of various “discharge scenarios” should be investigated in cooperation with TransAlta. ${ }^{168}$

At the end of the two-year study, Eaton and BNP's Aquatic Specialist contacted TransAlta about the possibility of increasing stream flows in the Spray River. The company declined to consider releasing more water into the river, citing costs as the reason. ${ }^{169}$ Releasing stored water to supplement the Spray River flows would reduce the amount of water available to generate "top up" power during periods of peak demand, which fluctuate seasonally, daily, and hourly. ${ }^{170}$ TransAlta would also have to install new infrastructure in the Canyon Dam to maintain a larger continuous release. ${ }^{171}$

Canada's Minister of the Environment approved a new management plan for BNP in $2010 .{ }^{172}$ None of its recommendations relate to the Spray River. Instead of spending resources on what seems now to be regarded as an intractable problem, Parks Canada and BNP officials have chosen to address concerns that will produce tangible results and fall within their own control (that is, they do not require negotiations with outside parties, such as TransAlta), such as eliminating non-native fish from the Devon Lakes (located in the northwest corner of BNP) and removing a defunct dam on Forty Mile Creek (located north of the town of Banff, near the southern end of Cascade Mountain). ${ }^{173}$

Ibid at 18.

Eaton, supra note 10 at vii. Ibid at 91 .

Ibid.

Interview of Charlie Pacas, Aquatic Specialist, Banff National Park by Sarah Nykolaishen and Nigel Bankes (5 July 5 2011) [Pacas Interview].

Schlinder \& Pacas, supra note 3 at 5-8.

Drury Interview, supra note 145.

Parks Canada, Banff National Park of Canada: Management Plan, 2010 (Ottawa: Parks Canada, 2010), online: Parks Canada < www.pc.gc.ca/pn-np/ab/banff/plan/ /media/pn-np/ab/banff/pdf/2010/ BanffManagement-Plan-EN-2010.ashx>.

Pacas Interview, supra note 169. 
The effects of the Spray Lakes Development on the native fish habitat in the Spray River have largely faded from public awareness. There do not appear to be any groups actively calling for TransAlta to modify its operations at the Canyon Dam and release more flow into the Spray River, and if the company were to do so at this time, the main beneficiaries would likely be brook, rather than cutthroat trout. Moreover, a major release event in the summer of 2011 has resulted in further damage to fish habitat in both the Spray River and Goat Creek. ${ }^{174}$ The future of the river is not altogether bleak, however. There is the possibility of future improvements in connection with efforts to revive Alberta's population of westslope cutthroat trout. As noted above, the species is currently being considered for listing under Canada's endangered species legislation, SARA ${ }^{175}$ In late 2011, COSEWIC completed a recommendation to list the species as threatened under $S A R A$. The recommendation has not yet come before the Governor in Council, but once it does, the Governor in Council has nine months to respond under the SARA scheme. ${ }^{176}$ On the recommendation of the Minister, the Governor in Council may decide whether or not to list the species, or refer the matter back to COSEWIC for further information or consideration. ${ }^{177}$ In the event that the Governor in Council accepts the proposal, SARA imposes several important duties on federal ministers and other federal decision-makers, including the duty to identify and legally protect "critical habitat" and the duty to prepare a recovery strategy and action plan. ${ }^{178}$ There could be consequences for TransAlta's operations at the Canyon Dam if critical habitat is identified in the stretch of the Spray River between the Canyon Dam and the Bow River and if the dam operations are found to "destroy" any part of that habitat. ${ }^{179}$

Mechanical problems at TransAlta facilities led TransAlta to release large volumes of water down both the Spray River and Goat Creek. TransAlta began diverting significant volumes of water down Goat Creek on 3 June 2011 (following a failure at the Spray Plant on 23 May 2011). Water then breached the spillway at Canyon Dam and entered the Spray River in mid-July 2011. Abnormally high water and turbidity levels in both the Spray and the Goat caused damage to fish habitat and led to the closure of popular trails, as well as a loss of business for fishing guides (Cathy Ellis, "High water may harm trout fishery,” Rocky Mountain Outlook (28 July 2011), online: Rocky Mountain Outlook <http://www.rm outlook.com/article/20110728/RMO0801/307289986/0/RMO0904>). Since the incident, crews from TransAlta and Parks Canada have been working together on a mitigation project to restore and create fish habitat on the Spray River. These efforts have involved placing hundreds of trees in the river to create pool habitat (see Banff National Park of Canada, "Update: Spray River Mitigation Project” (1 November 2011), online: Parks Canada <http:/www.pc.gc.ca/pn-np/ab/banff/plan/aquatiques-aquatics/ Spray2011.aspx>). Supra note 2.

Ibid, s 27.

Ibid, s 27(1.1).

Ibid, ss 37, 41(1)(c), 47, 57. With respect to aquatic species, s 2(1) of SARA defines "habitat" as "spawning grounds and nursery, rearing, food supply, migration and any other areas on which aquatic species depend directly or indirectly in order to carry out their life processes, or areas where aquatic species formerly occurred and have the potential to be reintroduced." The same section defines "critical habitat" as "the habitat that is necessary for the survival or recovery of a listed wildlife species and that is identified as the species' critical habitat in the recovery strategy or in an action plan for the species." The destruction of critical habitat is referred to in s 58(1) of SARA, which states that "no person shall destroy any part of the critical habitat of any listed endangered species or of any listed threatened species - or of any listed extirpated species if a recovery strategy has recommended the reintroduction of the species into the wild in Canada - if... (b) the listed species is an aquatic species.” SARA does not define destruction in relation to habitat; however, case law makes it clear such an activity must be defined by reference to the characteristics or attributes of the critical habitat that led to its identification as critical for the purposes of that species (see Nigel Bankes, "Protecting Listed Aquatic Species Under the Federal Species at Risk Act: The Implications for Provincial Water Management and Provincial Water Rights," 25 Journal of Environmental Law and Practice [forthcoming in 2012]). In the case law, see in particular Canada (Minister of Fisheries and Oceans) v David Suzuki Foundation, 2012 FCA 40, 427 NR 110 at paras 43, 150. It should be noted here as well that native stocks of westslope cutthroat trout have already been listed as threatened in Alberta under the Wildlife Act, RSA 2000, c W-10. A joint federal-provincial team was assembled in 2011 to develop a recovery plan for the species — the Alberta Westslope Cutthroat Recovery Team. The Recovery Team represented a broad range of interest and expertise, including biologists from the Fish and Wildlife Division of Alberta Environment and Fisheries and the 
Interest is also growing in the broader effects of TransAlta facilities on the Bow River system and the question of whether facility operations might be modified to better meet the needs of other water users and the environment. The Bow River Project Research Consortium (the Consortium) was formed in May 2010 to examine options for re-managing the Bow River system. Member organizations include irrigation districts, the City of Calgary, the Bow River Basin Council, and environmental non-government organizations, such as Trout Unlimited Canada.

The Consortium released its final report in December 2010. ${ }^{180}$ The report begins by noting that TransAlta has been the main influence on the storage and release of water in the Bow River and its tributaries since $1911 .^{181}$ From the perspective of the Consortium, the "managed" nature of the Bow River (that is, the fact that TransAlta controls the timing and flow rate of the river) presents opportunities for water users and the environment, because the river can be "re-managed" to better meet these needs. ${ }^{182}$ The Consortium used an interactive simulation model, the Bow River Operational Model (the BROM), to quantify and map water supply and usage on the river system, test out different scenarios, and ultimately address the question of how best to re-manage the river system. ${ }^{183}$ Using the BROM, the Consortium compared a number of scenarios to the base case scenario, or current operations on the Bow River system. By comparing the opportunities and costs of various scenarios, the Consortium identified a preferred scenario. This scenario would require a number of major changes from current operations, including: (1) doubling the capacity of the Langdon Reservoir (a large irrigation storage reservoir located east of Calgary); (2) stabilizing the Lower Kananaskis Lake at 1,663.5 m (3.5 m less than its current full supply level) and reducing annual fluctuations of its level; and (3) steadier discharge flows into the Kananaskis River from the Pocaterra power plant. ${ }^{184}$

The key feature of the preferred scenario is its "water bank" approach. Water-banking involves meeting the needs of downstream users by releasing water from upstream reservoirs. ${ }^{185}$ Under the preferred scenario, 60,000 acre-feet of water would be available for downstream use through water-banking, or reserving a certain proportion of upstream storage for the needs of downstream users. ${ }^{186}$ This idea hearkens back to what Parks Canada had in

Department of Fisheries and Oceans, larger industry groups such as TransAlta and the Canadian Association of Petroleum Producers, and environmental non-governmental organizations such as Trout Unlimited Canada. The Recovery Team completed its draft plan in November 2011. The plan must be reviewed by the Province's Species at Risk coordinator and the Director of Fisheries. The plan will then be discussed by the provincial Endangered Species Conservation Committee (ESCC), which is responsible (under section 6(1) of the Wildlife Act) for advising the Minister on the adoption of recovery plans.

Bow River Research Consortium, Bow River Project: Final Report (Edmonton: Alberta Water Research Institute, 2010), online: Alberta Water Portal <http://www.albertawater.com/index.php/component/ docman/doc_download/29-bow-river-project-full-report-march-2011?Itemid=>. Ibid at 1.

Ibid.

Ibid at 10 .

Ibid at 33.

Ibid at 24 .

Ibid. The Consortium suggests that the preferred scenario could be further enhanced by restoring the Spray Lakes Reservoir to its original design specifications. This would provide access to an additional 61,000 acre-feet of water. The Consortium writes: "The additional storage in Spray is drained down to generate additional power and is used in combination with the other reservoirs. This results in higher water levels in the other reservoirs for a longer period, likely creating environmental, recreational, aesthetic and other benefits" (ibid). This points to the fact that there are tradeoffs to be made between the operation of storage on the Spray and TransAlta's facilities elsewehere including on the Kananaskis. 
mind when it suggested that Calgary Power increase the storage capacity of the Spray Lakes Reservoir by 20,000 acre-feet, with those waters to be available on request to meet a variety of downstream needs.

TransAlta has no plans to implement the Consortium's recommendations at present. However, the company recognizes the significant water management issues facing the Bow River Basin and has been in active, ongoing discussions with the province about alternative management options since 2009. ${ }^{187}$ TransAlta did not participate directly in the Bow River Project out of concerns about the perceived conflict of interest that may arise if the company took part in a stakeholder group intended to provide recommendations to the province, while at the same time negotiating with the province. ${ }^{188}$

\section{PARAgraph 16 of THE Alberta Natural Resource Transfer Agreement}

Since Minister MacKinnon set the minimum flow requirement for the Spray/Bow River junction at 200 cfs in 1949, there has been little discussion of the legal implications of paragraph 16 of the Alberta NRTA, and in particular, whether the paragraph might provide a legal basis for restoring natural flows in the Spray River. This section provides some additional background on the Alberta NRTA, considers the question of how the phrase "to preserve the scenic beauties of the said parks" might be interpreted today, and discusses whether the federal government exhausted its right to set a minimum flow requirement for the Spray River in 1949.

The Alberta NRTA is part of the Constitution of Canada. ${ }^{189}$ Paragraph 16 was one of three paragraphs in the Alberta NRTA dealing with national parks. ${ }^{190}$ The national parks provisions of the three prairie NRTAs ${ }^{191}$ and the Railway Belt and Peace River Block Agreement ${ }^{192}$ with British Columbia are not identical. The Alberta agreement was the only one of the four

Water within the Spray system is particularly valuable to TransAlta since it can be flowed through a succession of plants as noted in Part III of this article. 2012 [on file with authors]. Ibid.

Constitution Act, 1982, being Schedule B to the Canada Act 1982 (UK), 1982, c 11, s 52(2) and Schedule I, item 16. The extensive case law on the implications of the constitutional status of the NRTAs is canvassed in Gerard V La Forest, Natural Resources and Public Property under the Canadian Constitution (Toronto: University of Toronto Press, 1969). The most important cases deal with paragraphs 1 and 2 of the Alberta NRTA and include Spooner Oils Ltd v Turner Valley Gas Conservation Board, [1933] SCR 629 and West Canadian Collieries Ltd v Alberta (AG), [1953] 3 DLR 145 (PC). Other cases deal with the Indians and Indian Reserves provisions of the NRTAs and include $R v$ Badger, [1996] 1 SCR 771. There are fewer decisions dealing with the parks clauses of the NRTAs (paras 10-13 of the Alberta NRTA), and none discuss the flow provision of the parks clauses: see e.g. $R v$ Hughes (1958), 26 WWR 280 (Alta Dist Ct); Re Rush and Tompkins Construction Ltd (1961), 28 DLR (2d) 441 (BCSC). A particularly striking case dealing with a constitutionalized agreement is Prince Edward Island v Canada, [1976] 2 FC 712, 66 DLR (3d) 465 (TD), aff'd Canada v Prince Edward Island, [1978] 1 FC 533, 83 DLR (3d) 492. For general discussion see Nigel Bankes, "Constitutionalized Intergovernmental Agreements and Third Parties: Canada and Australia” (1992) 30:2 Alta L Rev 524. Paragraph 14 of the Alberta NRTA identifies the parks and provides for their continuation as parks and for the administration and control of such parks (including mines and minerals) to remain with Canada and paragraph 15 deals with the legislative authority of Canada and Alberta within the boundaries of the parks. For further discussion see Bankes, “Constitutional Problems,” supra note 29.

191 See The Manitoba Natural Resources Transfer Act, CCSM c N30 [Manitoba NRTA]; Saskatchewan Natural Resources Act, SC 1930, c 41 [Saskatchwan NRTA]; Alberta NRTA, supra note 6.

192 Railway Belt Re-transfer Agreement Act, SBC 1930, c 60 [Railway Belt and Peace River Block Agreement]. 
agreements to provide for the removal of lands from a park to accommodate a commercial development. ${ }^{193}$ Similarly, while the Manitoba agreement does not contain a provision in relation to flows of water to protect scenic values, ${ }^{194}$ there are such provisions in the Saskatchewan NRTA ${ }^{195}$ and in British Columbia's Railway Belt and Peace River Block Agreement. ${ }^{196}$ The provisions are not completely identical, since it is only in the case of Alberta that the provision is expressed in conditional terms (that is, "upon the exclusion of the said areas"). ${ }^{197}$ In each of the other cases, the commitment is more open-ended. While we are not aware of the precise reasons for the difference in language between these agreements in relation to water flows, the historical record is clear in showing that BNP was the focus of the lands that were to be excluded from existing parks in Alberta and that the particular lands included the lands required for the development of the Spray. ${ }^{198}$ Furthermore, the geography of the mountain parks is such that there are very few cases in which provincial lands in Alberta are upstream of the national parks. The mountains are indeed our water towers and, in most cases, waters flow from the national parks onto provincial lands. This is true, for example, of the majority of the watershed of the Bow River; the upper reaches of the Spray River provide the stand out exception.

The second part of paragraph 16 does, therefore, impose a constitutional obligation on the province, but the obligation is only triggered to the extent that the Minister of the Interior fixes the flows necessary "to preserve the scenic beauties of the said parks." As we have seen, the Minister did ultimately establish a minimum flow for the Spray River at its confluence with the Bow. The manner in which this happened is discussed in detail above, and that discussion shows that a number of other values were also discussed by the relevant parties in addition to "scenic beauties"; these included water for fish, water for fire-fighting purposes, and water for sewage dilution flows for the Banff Springs Hotel located right at the confluence of the Spray and the Bow and adjacent to Bow Falls.

The range of values considered gives rise to some interesting interpretive questions that may still be relevant today. For example, how should we interpret the term "scenic beauties of the parks"? Should we interpret it literally and in the context of the times, or should we interpret it more contextually, taking into account a modern understanding of the purposes for which national parks are established, but also in light of the range of values that ended up being discussed in 1949? This might lead us to conclude that the provision is actually designed to protect ecosystem function, rather than simply aesthetic concerns as traditionally understood. Such an interpretive approach might draw on the living tree, or "progressive" and purposive approach to the interpretation of constitutional instruments which has been applied by the Privy Council and the Supreme Court of Canada, ${ }^{199}$ not only to the

See Alberta NRTA, supra note 6 at para 16 .

Manitoba NRTA, supra note 191 at paras 15-16.

Saskatchewan NRTA, supra note 191 at para 16.

Railway Belt and Peace River Block Agreement, supra note 192, article 18.

See Alberta NRTA, supra note 6 at para 16.

See Lothian, supra note 33 at 16-17. Coal bearing lands in Banff and Jasper were also identified for withdrawal from the mountain parks.

See e.g. Edwards v Canada (AG), [1930] AC 124 at 1366 (PC). 
Constitution Act, $1867,{ }^{200}$ but also to the Canadian Charter of Rights and Freedoms ${ }^{201}$ and to section 35 of the Constitution Act, $1982 .^{202}$ This approach might also draw on a similar trend in international law to interpret open-textured terms in international treaties (or in this case an intergovernmental agreement) in an evolutive way and in harmony with more general developments in international law. ${ }^{203}$ Taken together, these developments suggest that a court should be prepared to take a broad purposive approach to the interpretation of this constitutional instrument.

A second question might be whether or not the Minister's determination is an all or nothing affair. Or, to put the point more precisely, did the Minister's decision in 1949 establishing the minimum flow at the confluence of the Spray and Bow rivers exhaust the Minister's powers? We think that the general rule is that a statutory power, and even more so a constitutional power, is not exhausted by its exercise on one occasion, but may be exercised as the circumstances demand in order to respond to societal needs while being sensitive to vested interests. ${ }^{204}$

\section{What Does the SPRAy LaKes DeVelopment Story Tell Us About RESOURCE DEVELOPMENT DECISIONS?}

Decision-making about natural resource development occurs within a much different context today than it did when Calgary Power received its licence to transform the Spray Lakes into a reservoir. Nonetheless, it is worth highlighting two features of the Spray Lakes Development story. These features are worth noting because they can and do affect modernday decision-making about resource development, albeit to a lesser extent than in the past.

One important feature of the Spray Lakes Development story is the attitude of many key players towards investigating the full environmental implications of the proposed scheme before construction got underway. Most parties, including the province, Minister MacKinnon, the CPR, and Calgary Power, saw no need to use science to consider the effects of a 200 cfs minimum flow requirement in June, July, and August, much less the effects of

Supra note 29.

Part I of the Constitution Act, 1982, being Schedule B to the Canada Act 1982 (UK), 1982, c 11. See Law Society of Upper Canada v Skapinker, [1984] 1 SCR 357 at para 10; Hunter v Southam Inc, [1984] 2 SCR 145 at 155.

Being Schedule B to the Canada Act 1982 (UK), 1982, c 11. See R v Van der Peet, [1996] 2 SCR 507 at paras 21-22.

Article 31 of the Vienna Convention on the Law of Treaties, 23 May 1969, 1155 UNTS 331 (entered into force 27 January 1980) prescribes the rules for interpreting treaties. Paragraphs 2 and 3 provide that "[t]he context for the purpose of the interpretation of a treaty shall comprise, in addition to the text, including its preamble and annexes: ... (c) any relevant rules of international law applicable in the relations between the parties.” The academic commentary on this important provision includes Duncan French, “Treaty Interpretation and the Incorporation of Extraneous Legal Rules” (2006) 55:2 ICLQ 281; Campbell McLachlan, "The Principle of Systemic Integration and Article 31(3)(c) of the Vienna Convention” (2005) 54:2 ICLQ 279; Richard K Gardiner, Treaty Interpretation (Oxford, Oxford University Press, 2008) ch 7; Philippe Sands, "Treaty, Custom and the Cross-fertilization of International Law” (1998) 1 Yale Human Rts \& Dev LJ 85. The relevant case law favouring an evolutive interpretation of open textured terms includes the Case Concerning the Gabčkovo-Nagymaros Project (Hungary v Slovakia), [1997] ICJ Rep 7; Arbitration Regarding the Iron Rhine Railway (Belgium v Netherlands) (Permanent Court of Arbitration, 24 May 2005), online: Permanent Court of Arbitration $<$ http://www.pca-cpa.org/showpage.asp?pag_id=1155>.

Being sensitive to vested rights does not mean that such rights will always trump, but it does mean that it will be important to inquire into TransAlta's expectations (which included having to pay into an account in a water bank), the long period within which TransAlta has been able to operate its facilities, and changed circumstances, including the lower level at which TransAlta now operates the reservoir. 
the development as a whole on the Spray Lakes Valley. ${ }^{205}$ This may be partly explained by the fact that the parties were primarily concerned with only two issues. One was the effect of any minimum flow requirement on the volumes of water that Calgary Power/TransAlta would be able to run through the turbines of the Spray River Development. The second was the effects of the development on scenery in the town of Banff. Hence, Calgary Power measured flows in the Spray River near its junction with the Bow River to determine whether tourists would be able to the tell the difference between the Spray River in its natural state, and the Spray River post-damming, supplemented by a release from the reservoir. Perhaps the larger explanation, though, for why the parties did not consider studying the effects of the $200 \mathrm{cfs}$ minimum flow requirement, or the development as a whole, is that they were preoccupied with the short-term economic benefits of the scheme. As outlined above, decision-makers at both the provincial and federal levels of government had come to believe that Alberta's economic growth would stall unless Calgary Power was given the go-ahead to proceed with the development. Thus, decision-makers were unwilling to risk even a moment's worth of economic slowdown to consider whether the immediate benefits of the project would outweigh its long-term environmental costs.

In contrast with the proponent and federal and provincial officials, the National Parks Service felt there should be some scientific basis for the $200 \mathrm{cfs}$ minimum flow requirement. The Director of the National Parks Service, R.A. Gibson, recommended incorporating an environmental rationale for the requirement into an agreement between the federal government and Calgary Power in order to provide a legal basis for the government to demand greater stream flows in the future, if need be. This type of legal mechanism would likely have made it easier for Parks Canada to improve the fish habitat in the Spray River. That said, a number of opportunities to improve stream flows appear to have gone unexploited by Parks Canada. For instance, the agency did not take advantage of the water bank that Calgary Power agreed to provide in 1949 (that is, the additional 20,000 acre-feet of storage, which was set aside for forest fire prevention and fish flow purposes). Parks Canada could also have taken steps to ensure that Calgary Power maintained the valve that was required as a term of its licence and to prevent the company from spilling water down Goat Creek to meet the minimum flow requirement at the Spray/Bow River junction. Perhaps the point could have been pressed that releasing water through the Canyon Dam was an implied term of Calgary Power's agreements with the province and/or MacKinnon. Finally, the question remains whether Parks Canada could have obtained a larger continuous release at the Canyon Dam in exchange for its decision to relax the $200 \mathrm{cfs}$ minimum flow requirement in 1979.

The second important feature of the Spray Lakes Development story is the extent to which corporate interests influenced government decision-making. One striking example of this influence is the latter half of section 16 of the Alberta NRTA, which the federal government bargained for in the course of natural resources transfer negotiations for the purpose of protecting the CPR's interests in Banff. At the provincial level, Calgary Power easily obtained an amendment to the WRA in order to protect its water licence from priority use applications and to put the minds of its investors at ease.

205 It is not clear to what extent any of the parties were familiar with the work of Miller and MacDonald, supra note 12, which predicted the effects of the reservoir and the Canyon Dam on cutthroat trout. 
This raises the question of why corporations, and Calgary Power in particular, had the ear of decision-makers. The answer to this question must relate, in part, to the way in which Calgary Power framed its reasons for wanting to develop the Spray Lakes Valley — namely in terms of Alberta's economic well-being. When the company petitioned the federal government about the Spray River minimum flow requirement, it focused entirely on Alberta's growing demand for power and the dire consequences that would result if construction did not start as soon as possible. ${ }^{206}$ This way of characterizing the project — as an urgent need that Alberta could not do without - appears to have had a strong effect on the province, which effectively accepted Calgary Power as its partner in dealings with the federal government, for example, by using the company's arguments as a basis for the flow requirement recommendation it gave to the federal government, and allowing Fraser, the company's solicitor, to make representations before the Senate's Natural Resources Committee on behalf of the province. The effect was also felt at the federal level, as MacKinnon met with company representatives to discuss the project, but rejected Gibson's suggestion to appoint a special commission to hear the views of other parties that would be affected by the Spray Lakes Development. Thus, it may be the case that decision-makers favoured Calgary Power's views over those of other parties, such as the National Parks Service, because the company claimed to be acting in the best interests of the province as a whole.

Present-day decision-making about natural resources development occurs in a much different legal and social context than did decisions related to the Spray Lakes Development. In general, there are more laws in place to protect against the sorts of environmental damage caused by the development and environmental values have become widespread throughout society. Despite these changes, however, decision-making about natural resource development remains susceptible to inadequate scientific study of the long-term environmental consequences of projects (and the weighing of those consequences against the short-term economic benefits of the project) and to the exercise of discretionary powers by ministers and departmental officials in ways that favour private corporate interests over the more general public good.

\section{CONCLUSION}

The Spray Lakes Development had an enormous impact on the Spray River and its native habitat, especially in the two decades immediately after construction, when there was no water released from the reservoir into the Spray River. The health of the river improved somewhat in the early 1980s after TransAlta began releasing a steady flow at the Canyon Dam. However, stream flows were still not sufficient to revive native fish populations, and by that point invasive non-native species, such as brook trout and rainbow trout, had established a strong foothold in the river. In subsequent years, more attention has been given to the poor state of BNP's aquatic ecosystems, particularly through the Banff-Bow Valley Report. In fact, the Banff-Bow Valley Report prompted Parks Canada to renew its efforts to improve the state of the Spray River by working with TransAlta to restore natural stream flows. Although the state of the Spray River has, in large part, faded from public awareness, there has been co-operation between TransAlta and Parks Canada to address further threats 
to fish habitat, such as flooding. The possible listing of Alberta's population of westslope cutthroat trout under SARA could also have positive implications for the river. Finally, the work of the Bow River Research Consortium creates hope that the ecological health of other portions of the Bow River system might improve as a result of modifying the operation of existing facilities.

Although set in the past, the story of the Spray Lakes Development has a great deal of contemporary relevance. The story highlights the many challenges associated with restoring instream flow and aquatic ecosystems in rivers and streams downstream of hydro developments. The story also explains how the federal government obtained a constitutional right to set a minimum flow requirement for the Spray River and how that right may still be used today to secure a range of values within BNP. Finally, the story underscores the need for decision-makers to consider the long-term impacts of large-scale natural resource development projects on the environment, and to weight those effects properly when deciding whether to approve projects that promise short-term economic gains. 